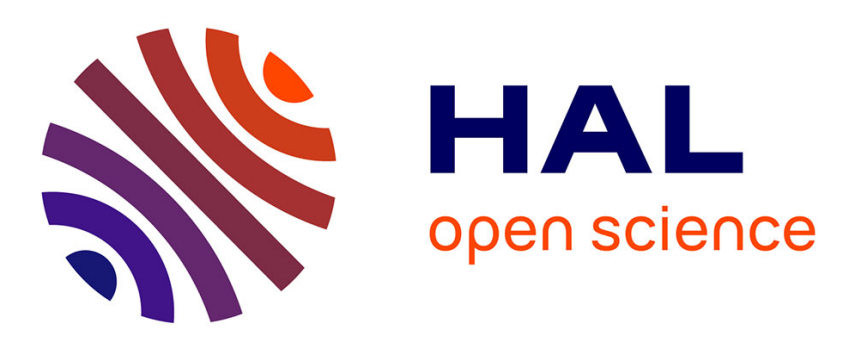

\title{
Bipyramidal anatase TiO2 nanoparticles, a highly efficient photocatalyst? Towards a better understanding of the reactivity
}

S. Pigeot-Rémy, Frédéric Dufour, A. Herissan, V. Ruaux, F. Maugé, R. Hazime, C. Foronato, C. Guillard, C. Chaneac, O. Durupthy, et al.

\section{To cite this version:}

S. Pigeot-Rémy, Frédéric Dufour, A. Herissan, V. Ruaux, F. Maugé, et al.. Bipyramidal anatase TiO2 nanoparticles, a highly efficient photocatalyst? Towards a better understanding of the reactivity. Applied Catalysis B: Environmental, 2016, 203, pp.324-334. 10.1016/j.apcatb.2016.10.031 . hal01405729

\section{HAL Id: hal-01405729 \\ https://hal.sorbonne-universite.fr/hal-01405729}

Submitted on 30 Nov 2016

HAL is a multi-disciplinary open access archive for the deposit and dissemination of scientific research documents, whether they are published or not. The documents may come from teaching and research institutions in France or abroad, or from public or private research centers.
L'archive ouverte pluridisciplinaire HAL, est destinée au dépôt et à la diffusion de documents scientifiques de niveau recherche, publiés ou non, émanant des établissements d'enseignement et de recherche français ou étrangers, des laboratoires publics ou privés. 


\title{
Bipyramidal anatase $\mathrm{TiO}_{2}$ nanoparticles, a highly efficient photocatalyst? Towards a better understanding of the reactivity.
}

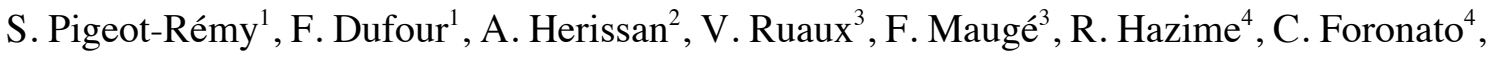 \\ C. Guillard ${ }^{4}$, C. Chaneac ${ }^{1}$, O. Durupthy ${ }^{1}$, C. Colbeau-Justin ${ }^{2}$, S. Cassaignon ${ }^{1 *}$ \\ ${ }^{1}$ Sorbonne Universités, UPMC Univ Paris 06, CNRS, Collège de France, Laboratoire de \\ Chimie de la Matière Condensée de Paris (LCMCP), 11 place Marcelin Berthelot, F-75005, \\ Paris, France \\ ${ }^{2}$ Univ Paris-Sud, Laboratoire de Chimie Physique, UMR8000, 91405 Orsay, France \\ ${ }^{3}$ ENSICAEN, Univ de Caen, Laboratoire Catalyse et Spectrochimie, CNRS, 6 Boulevard \\ Maréchal Juin, 14050 Caen Cedex, France \\ ${ }^{4}$ Univ de Lyon 1, CNRS UMR 5256, IRCELYON, Institut de recherches sur la catalyse et \\ l'environnement de Lyon, 69626 Villeurbanne, France \\ * Corresponding author
}

\begin{abstract}
Anatase nanoparticles with shape controlled bipyramidal morphology $\left(\mathrm{TiO}_{2}\right.$-A-bipy $)$ exhibited mainly $\{101\}$ facets were synthesized through the sol-gel method and then used for the photodegradation of three model pollutants - Rhodamine B, phenol and formic acid under UV-A radiation exposure. These titania samples exhibit better photocatalytic efficiency than the commercial $\mathrm{TiO}_{2}-\mathrm{P} 25$ reference for the dye degradation while this one demonstrates a higher activity for both phenol and formic acid. Moreover, supplementary washings of the particles significantly enhanced their photocatalytic efficiency in any case. To better understand these differences in term of photoactivity and the role of the $\mathrm{TiO}_{2}$ surface according to the nature of the targeted organic pollutant, various characterization techniques such as XRD, TEM and $\mathrm{N}_{2}$-sorption were used. Their surface properties were studied by FTIR, TRMC and EPR. The presence of more acidic sites on $\mathrm{TiO}_{2}$-A-bipy surface could explain the faster degradation of the dye molecule through surface-mediated reactions. On the other side, a better generation and separation dynamic of photogenerated charges for $\mathrm{TiO}_{2}-\mathrm{P} 25$
\end{abstract}


could account for its higher photocatalytic efficiency for both formic acid and phenol degradation. This study shows that even if a quick test of dye degradation is mostly used in literature to confirm the efficiency of a photocatalyst, further investigation is often needed.

\section{Introduction}

In recent years, semiconductor-based heterogeneous photocatalysis has attracted a great deal of interest because of its promising applications in the degradation of organic compounds and biological pollutants in both aqueous and gaseous phases ${ }^{1-4}$ as well as in hydrogen gas production through water splitting. ${ }^{5}$ Photocatalysis is an environmentally friendly Advanced Oxidation Process (AOP) ${ }^{6}$ which presents significant benefits as it can employ a chemically stable and non-toxic photocatalyst, namely $\mathrm{TiO}_{2}$, with solar light as a cost-effective and renewable source of energy.

The activity of the $\mathrm{TiO}_{2}$ photocatalyst is a crucial point concerning the clean-up process and its enhancement can be obtained by either inducing photocatalytic degradation under visiblelight ${ }^{7,8}$ or increasing the photocatalytic degradation kinetics under UV radiation exposure. ${ }^{1,7}$ Several parameters such as crystal structure, crystallite size, shape, crystallinity, surface area or metal doping are critical points with reference to the photocatalytic performance of the nanosized $\mathrm{TiO}_{2}{ }^{9-13}$. Among the three common polymorphs of titania, anatase and rutile $\mathrm{TiO}_{2}$ are preferentially used as photocatalysts, and the metastable anatase structure has been widely reported as the most active for such property. ${ }^{7,914}$ Extensive research in the field of materials has been performed to develop photoactive semiconductor demonstrating a better photocatalytic activity than the mixed-phase and most widely used $\mathrm{TiO}_{2}-\mathrm{P} 25$ (from Evonik ${ }^{\circledR}$ ) considered as a reference for the degradation of both chemical compounds ${ }^{15,16}$ and microorganisms. ${ }^{17,18}$ Most of these works were focused on syntheses of different anatase $\mathrm{TiO}_{2}$ shapes or titania based nanocomposites by sol-gel method due to the possibility it offers to control structural, dimensional and morphological characteristics of the nanoparticles. ${ }^{19,20}$ Moreover, sol-gel chemistry in aqueous solution (from Ti(IV) salt) is one of the simplest, cost effective, and green commonly used methods to obtain nanosized titania. ${ }^{21-23}$ Variation of some parameters such as $\mathrm{pH}$, presence of organics, temperature and the nature of the precursor allows the control of the size, morphology and exposed faces of the oxide 
materials. ${ }^{22,24-26}$ In spite of this wide range of research aimed to develop new $\mathrm{TiO}_{2}$ anatase nanoparticles with high photoactivity, the role of the surface has not yet been completely clarified. Indeed, it is the place where different mechanistic steps of the pollutant degradation may proceed but it is only a part of the whole photocatalytic process. Moreover, due to the diversity of the photocatalytic degradation mechanisms, it may be misleading to claim the high activity of a material by testing it with single type of model pollutant under very restrictive catalytic conditions. However, most of the published studies deal with the degradation of a single organic dyes. Beside the simplicity to follow their degradation, the organic dyes are not necessary good models of pollutants and do not always prove the quality of a catalyst.

The main contribution of this work is to explain why the efficiency of a new photocatalytic material must be tested on several pollutants that present significantly different degradation mechanisms. Indeed, due to the subtle balance between intrinsic quality of a photocatalytic material and its surface properties, the degradation performance strongly depends on the pollutant to degrade. This work provides a better understanding of the surface reactivity of bipyramidal $\mathrm{TiO}_{2}$ nanoparticles synthesized from soft chemistry in water and its role in the photocatalytic process through the degradation of three model organic pollutants in water. Moreover, successive washings after the synthesis may also impact on their surface reactivity and potentially on their photocatalytic activity. A detailed characterization in term of structure, morphology and size of synthesized $\mathrm{TiO}_{2}$ nanoparticles was first carried out especially through X-Ray Diffraction (XRD) and Transmission Electron Microscopy (TEM) analysis. The different photocatalytic activity of the $\mathrm{TiO}_{2}$ samples according to the type of pollutants were then studied and compared to the high-activity of $\mathrm{TiO}_{2}-\mathrm{P} 25$ reference. The determination of the relative surface acidity of the samples and especially the presence of both Brönsted and Lewis sites was carried out by in situ Fourier Transformation Infrared Spectroscopy (FT-IR) using pyridine as probe, and was correlated to the photocatalytic activity of the samples. The stability of the charge-carriers at the $\mathrm{TiO}_{2}$ surface and the production of radical species were studied by Time-Resolved Microwave Conductivity (TRMC) and Electron Paramagnetic Resonance Spectroscopy (EPR) and their relationship with the photoactivity of the samples was also investigated.

\section{Experimental details}




\subsection{Materials}

Titanium tetrachloride $\left(\mathrm{TiCl}_{4}\right)$, L-Glutamic acid $\left(\mathrm{C}_{5} \mathrm{H}_{9} \mathrm{NO}_{4}\right)$, Rhodamine $\mathrm{B}(\mathrm{RhB}$, $\left.\mathrm{C}_{28} \mathrm{H}_{31} \mathrm{ClN}_{2} \mathrm{O}_{3}\right)$, formic acid $(\mathrm{HCOOH})$, phenol $\left(\mathrm{C}_{6} \mathrm{H}_{5} \mathrm{OH}\right)$ and pyridine $\left(\mathrm{C}_{5} \mathrm{H}_{5} \mathrm{~N}\right)$ were purchased from Sigma Aldrich. Pyridine was dried on molecular sieves prior to its use. All chemicals were analytic grade reagents used without further purification. Spin trapping agent 5,5-dimethyl-1-pyrroline N-oxide (DMPO, Aldrich) was stored at $-18{ }^{\circ} \mathrm{C}$ before use. The Aerosil $\mathrm{TiO}_{2}-\mathrm{P} 25$, supplied from Evonik ${ }^{\circledR}$, was used as a reference. It contains mainly anatase in crystalline form (anatase/rutile $=85 / 15$ ) with an average particle size of $25 \mathrm{~nm}$ and a specific surface area of $50 \mathrm{~m}^{2} \mathrm{~g}^{-1}$. It was used as received. Suspensions were prepared using water from a Millipore Waters Milli-Q purification unit.

\subsection{Syntheses}

The synthesis of sample ( $\mathrm{TiO}_{2}$-A-Bipy) was carried out using the sol-gel approach in aqueous solution. This synthesis was adapted from the procedure reported by Durupthy et al. ${ }^{21}$ A stock solution with $\mathrm{Ti}(\mathrm{IV})$ concentration of $1 \mathrm{~mol} \mathrm{~L}^{-1}$ was prepared by dilution of $\mathrm{TiCl}_{4}$ in $\mathrm{HCl} 3$ mol L ${ }^{-1}$ solution. In addition to the $30 \mathrm{~mL}$ of Ti(IV) stock solution, a $1.98 \mathrm{~g}$ amount of glutamic acid (GA) was introduced at room temperature under stirring into $100 \mathrm{~mL}$ of Milli-Q water in order to obtain a $[\mathrm{GA}] /[\mathrm{Ti}]$ molar ratio of 0.5 . No precipitation occurred. The $\mathrm{pH}$ of the solution was then set to 4 by addition of sodium hydroxide solution and the sample volume was completed to $300 \mathrm{~mL}$ with water. A white precipitate immediately appeared (Ti(IV) precipitated quantitatively) and this suspension was placed in a closed glass vessel at $120^{\circ} \mathrm{C}$ in an oven for $48 \mathrm{~h}$.

\subsection{Washing procedure}

The resultant precipitates were collected by centrifugation, washed first with water, then with nitric acid $\left(3 \mathrm{~mol} \mathrm{~L}^{-1}\right)$ and one last time with water for $\mathrm{TiO}_{2}-\mathrm{A}-\mathrm{Bipy}-3 \mathrm{w}$ powder. $\mathrm{For} \mathrm{TiO}_{2}-\mathrm{A}$ Bipy-8w powder, successive washings were performed in the following order: water, $\mathrm{HNO}_{3}$, water, ethanol $\left(96 \% \%_{\text {vol }}\right), \mathrm{NaOH}\left(1 \mathrm{~mol} \mathrm{~L}^{-1}\right)$, water, $\mathrm{HNO}_{3}$ and finally water. Washings with nitric acid were aimed to eliminate potential amorphous compounds and to improve the dispersion of the nanoparticles by charging their surfaces. The other washing steps allowed the elimination of residual organic molecules. 


\subsection{Characterization}

2.4.1 XRD measurements. The phase and the particle size distribution analyses of $\mathrm{TiO}_{2}$ powders were performed with a Bruker D8 X-ray diffractometer operating in the BragBrentano reflection mode equipped with a nickel filter to select the $\mathrm{Cu}-K_{\alpha}$ radiation. The data were collected in the $2 \theta=10-70^{\circ}$ range with $0.05^{\circ}$ steps. Pattern analyses were performed using EVA software (Bruker AXS) and the ICDD DD View PDF-4+ 2009 RDB base (PDF number 00-021-1272 for anatase, 00-021-1276 for rutile and 04-007-0758 for brookite). The proportions of the different $\mathrm{TiO}_{2}$ polymorphs were assessed from the relative areas of the anatase (101), brookite (121) and rutile (110) diffraction lines obtained after diagram deconvolution and according to a previously described procedure. ${ }^{25}$ For average size of anatase crystallites, (101), (004) and (200) diffraction lines were exploited as reported previously. ${ }^{22}$ In terms of crystallite size measurements, the evaluated error is $\pm 0.5 \mathrm{~nm}$.

2.4.2 TEM analysis. The morphology and the average particle size of the samples were analyzed by transmission electron microscopy (TEM) using a Tecnai spirit G2 apparatus equipped with a Gatan $\mathrm{CCD}$ and operating at $120 \mathrm{kV}\left(\mathrm{LaB}_{6}\right)$. Carbon-coated copper grids were used as sample holders. For the evaluation of average size $\mathrm{TiO}_{2}$ particles, more than 150 particles were considered on several TEM pictures. High resolution TEM (HRTEM) was performed at $200 \mathrm{kV}$ using a Jeol-Jem 2011HR apparatus $\left(\mathrm{LaB}_{6}\right)$.

2.4.3 Raman spectroscopy. Raman spectra were recorded at room temperature in the 100-700 $\mathrm{cm}^{-1}$ range using the Raman Analyzer RXN1 microprobe (Kaiser Optical Systems, Inc.) equipped with a $785 \mathrm{~nm}$ high-powered near-IR diode laser for excitation and a Leica microscope as microprobe.

2.4.4 Surface area measurements. The specific surface area measurements were carried out by $\mathrm{N}_{2}$ adsorption isotherm at $77 \mathrm{~K}$ using a Belsorb Max instrument. Prior to measurements, $\mathrm{TiO}_{2}$ powders were degassed under a primary vacuum at $150{ }^{\circ} \mathrm{C}$ and flowing nitrogen gas overnight using a Belprep II instrument in order to remove any adsorbed organic compounds and water molecules. The BET method was applied to only determine the specific surface area.

2.4.5 FT-IR analysis. The surface groups and the acidity of the $\mathrm{TiO}_{2}$ nanoparticles were 
studied by FT-IR using pyridine as a basic spectroscopic probe. Infrared spectra were recorded on self-supported discs $\left(\sim 2 \mathrm{~cm}^{2}\right.$, i.e. $\left.\sim 20 \mathrm{mg}\right)$ placed into an infrared quartz cell ( $\mathrm{KBr}$ windows) connected to a vacuum line. The FT-IR spectrophotometer was a Nicholet Nexus apparatus equipped with an extended $\mathrm{KBr}$ beam splitter and a mercury cadmium telluride (MCT) detector (resolution: $4 \mathrm{~cm}^{-1}$ ). Spectra were recorded at room temperature from 4000 to $400 \mathrm{~cm}^{-1}$ with an accumulation of 256 scans with a step of $1 \mathrm{~cm}^{-1}$ (analogical resolution of 0.5 $\left.\mathrm{cm}^{-1}\right)$. Prior to the adsorption experiment, samples were activated by heating $\left(3{ }^{\circ} \mathrm{C} \mathrm{min}^{-1}\right)$ to $200{ }^{\circ} \mathrm{C}$ under secondary vacuum $\left(\mathrm{P} \sim 10^{-4} \mathrm{~Pa}\right)$ and kept at this temperature for $2 \mathrm{~h}\left(\mathrm{~d}_{0}\right)$. After the activation (first recorded spectrum $\mathrm{d}_{0}$ ), pyridine was introduced into the cell via the vacuum line at equilibrium pressure (133 Pa). A second spectrum was recorded at room temperature $\left(20^{\circ} \mathrm{C}\right)$. The adsorbed pyridine was then evacuated under primary vacuum $\left(10^{-3}\right.$ $\mathrm{Pa}, \mathrm{d}_{1}$ spectrum), then under secondary vacuum $\left(10^{-4} \mathrm{~Pa}, \mathrm{~d}_{2}\right.$ spectrum $)$ and finally under secondary vacuum with increasing temperature $\left(20^{\circ} \mathrm{C}\right.$ for $\mathrm{d}_{3}, 50{ }^{\circ} \mathrm{C}$ for $\mathrm{d}_{4}, 100{ }^{\circ} \mathrm{C}$ for $\mathrm{d}_{5}, 150$ ${ }^{\circ} \mathrm{C}$ for $\mathrm{d}_{6}$ and $200{ }^{\circ} \mathrm{C}$ for $\mathrm{d}_{7}$ ).

2.4.6 TRMC measurements. The charge-carrier lifetimes in $\mathrm{TiO}_{2}$ after $\mathrm{UV}$ irradiation were determined by microwave absorption experiments using the TRMC method. Measurements were carried out as previously described. ${ }^{27}$ The incident microwaves were generated by a Gunn diode in the $\mathrm{K}_{\alpha}$ band (29-31 GHz). The experiments were performed at about 30.0 $\mathrm{GHz}$, frequency corresponding to the highest microwave power. Pulsed light source was a Nd:YAG laser providing an IR radiation at $\lambda=1064 \mathrm{~nm}$. TRMC signals have been excited by $10 \mathrm{~ns}(\mathrm{FWHM})$ pulses, repetition frequency of the pulses was $10 \mathrm{~Hz}$. UV light (355 nm) was obtained by tripling the IR radiation. The light energy density received by the sample was $1.3 \mathrm{~mJ} \mathrm{~cm}^{-2}$.

2.4.7 EPR spectroscopy. Photoinduced $\mathrm{HO} \cdot$ radicals formation was investigated using $\mathrm{TiO}_{2}$ suspensions prepared by dispersing $3 \mathrm{mg}$ of titania powder in $2 \mathrm{~mL}$ milliQ water homogenized in the dark during a 10 minutes-period under magnetic stirring. The suspension was then exposed to UV-A radiation during two minutes under vigorous stirring. A fresh solution of DMPO was then added to the suspensions of $\mathrm{TiO}_{2}$ with final concentrations of $1 \mathrm{~g}$ $\mathrm{L}^{-1}$ and $0.02 \mathrm{~mol} \mathrm{~L}^{-1}$ for the photocatalyst and the spin trap agent respectively. At various time intervals, few microliters of the suspensions were withdrawn and transferred into quartz capillary tubes (10 $\mu \mathrm{L}$ from Hirschmann Laborgeräte) placed in EPR quartz tube suitable for 
the spectrometer cavity. EPR spectra were performed at $22{ }^{\circ} \mathrm{C}$ with a Bruker EMX spectrometer. The EPR measurement was not affected by the solid suspension. The spectra acquisition and simulation were carried out using Bruker WINEPR program. The relative integral intensities of $\bullet$ DMPO-OH adduct were evaluated by the normalized doubleintegration procedure of experimental EPR spectra, making a quantitative comparison among the samples possible.

\subsection{Photoreactor and light sources}

All photocatalytic experiments were carried out in a cylindrical Pyrex reactor with a bottom optical window of diameter $3 \mathrm{~cm}$ through which the suspension was exposed to $\mathrm{UV}$ radiation. The UV light source was provided by a high-pressure mercury lamp (Philips HPK $125 \mathrm{~W}$ ) cooled with a water circulation cell located between the lamp and the lower side of the reactor to avoid the heating of the suspension. The irradiation spectrum was cut off over below 340 $\mathrm{nm}$ (UV-A) using a Corning 0.52 filter. The UV-A radiance intensity of $4.5 \mathrm{~mW} \mathrm{~cm}^{-2}$ was measured with a radiometer VLX-3W equipped with a $365 \mathrm{~nm} \pm 5 \%$ detector. For EPR spectroscopy, a Philips PL-L mercury lamp (18 W), emitting UV-A radiation with a peak emission at $365 \mathrm{~nm}$, was used as the light source.

\subsection{Experimental procedure}

For photocatalytic experiments, a volume of $30 \mathrm{~mL}$ of aqueous solution of each pollutant with an initial concentration of $50 \mathrm{ppm}$ for both formic acid and $\mathrm{RhB}$ and of $20 \mathrm{ppm}$ for phenol was introduced into the reactor. The $\mathrm{TiO}_{2}$ powder was then added with an optimal concentration of $1 \mathrm{~g} \mathrm{~L}^{-1}$, as usually reported in the literature for the degradation of organic pollutants. ${ }^{13,22,28,29}$ To ensure adequate homogenization, the suspensions were constantly magnetically stirred. All reactions were conducted at room temperature. The photocatalytic reaction experiments were initiated after the adsorption/desorption equilibrium was established by stirring the suspension for $30 \mathrm{~min}$ in the dark. It has been checked that the adsorbed quantity did not evolve anymore after this time (not shown). At regular time intervals, samples of $500 \mu \mathrm{L}$ were removed and filtered through $0.45 \mu \mathrm{m}$ Millipore filters to remove $\mathrm{TiO}_{2}$ nanoparticles before analysis.

\subsection{Chemical Analyses}


The concentration of formic acid was analyzed by HPLC using a Varian ProStar 230, a Varian ProStar 330 detector (detection at $210 \mathrm{~nm}$ ), and a Sarasep CAR-H (7.8 x $300 \mathrm{~mm}$ ) column. The flow rate was of $0.7 \mathrm{~mL} \mathrm{~min}^{-1}$. The injection volume was $50 \mu \mathrm{L}$ and the mobile phase was $\mathrm{H}_{2} \mathrm{SO}_{4}(5 \mathrm{mM})$. The concentration of phenol was also determined by HPLC with detection at $270 \mathrm{~nm}$. A reverse phase column (Superspher 100, $125 \mathrm{~mm}$ long, $4 \mathrm{~mm}$ i.d., Agilent Technologies) was used. The mobile phase was a mixture of water (99\%) supplemented with methanol (1\%), adjusted to $\mathrm{pH} 3$ with $\mathrm{H}_{3} \mathrm{PO}_{4}$. The concentration of $\mathrm{RhB}$ was monitored at a wavelength of $555 \mathrm{~nm}$ by visible spectroscopy $(400-800 \mathrm{~nm})$ using PerkinElmer Lambda 45 UV/Vis spectrophotometer. The characteristic absorption peak intensity of $\mathrm{RhB}$ at $555 \mathrm{~nm}$ was chosen to monitor the photocatalytic degradation kinetics as no significant shift in the wavelength was observed.

\section{Results and discussion}

\subsection{Structural and morphological properties}

As previously reported, the $\mathrm{X}$-ray diffractograms of both $\mathrm{TiO}_{2}$-A-Bipy samples (Figure 1) show pure anatase particles, resulting from the addition of glutamic acid during the sol-gel synthesis, which avoids the formation of the brookite structure. ${ }^{20}$ This complexing molecule is able to thermodynamically stabilize specific faces of the as-synthesized anatase structure through its adsorption or at least to control their growth rate. The Scherrer equation applied to the peaks of the $\mathrm{TiO}_{2}$-A-Bipy-3w XRD pattern led to a crystallite size of $14 \mathrm{~nm}$ along the [001] axis and $6 \mathrm{~nm}$ along the [100] axis. The anisotropy ratio (ratio of the dimensions in those two directions) was $\mathrm{r}=2.3$ for this sample. For $\mathrm{TiO}_{2}-\mathrm{A}-\mathrm{Bipy}-8 \mathrm{w}$, this characterization led to a crystallite size of $15 \mathrm{~nm}$ along the [001] axis and $6 \mathrm{~nm}$ along the [100] axis, with $\mathrm{r}=$ 2.5 along the [001] axis. The size for $\mathrm{TiO}_{2}$-A-Bipy-8w $\mathrm{TiO}_{2}$ revealed a slightly higher length that could be attributed to the loss of the smallest well-dispersed crystallites during the additional washing steps by means of a selective centrifugation process.

Raman spectra confirmed the absence of brookite and rutile phases for both $\mathrm{TiO}_{2}-\mathrm{A}-\mathrm{Bipy}$ powders as reported in Figure 2. Six Raman bands corresponding to the six Raman-active vibration modes in the anatase structure were clearly observed in the 100 to $700 \mathrm{~cm}^{-1}$ range: $144 \mathrm{~cm}^{-1}\left(\mathrm{E}_{\mathrm{g}}(1)\right), 197 \mathrm{~cm}^{-1}\left(\mathrm{E}_{\mathrm{g}}(2)\right), 399 \mathrm{~cm}^{-1}\left(\mathrm{~B}_{1 \mathrm{~g}}(1)\right), 513 \mathrm{~cm}^{-1}\left(\mathrm{~A}_{1 \mathrm{~g}}\right), 519 \mathrm{~cm}^{-1}\left(\mathrm{~B}_{1 \mathrm{~g}}(2)\right)$ and 639 $\mathrm{cm}^{-1}\left(\mathrm{E}_{\mathrm{g}}(3)\right) \cdot{ }^{30}$ However, we observed clear changes between the two Raman spectra in terms 
of bands intensity. In particular, one of the less intense bands $\left(\mathrm{E}_{\mathrm{g}}(1)\right)$ observed in the spectrum of $\mathrm{TiO}_{2}$-A-Bipy-3w, becomes one of the highest intensity peaks in $\mathrm{TiO}_{2}-\mathrm{A}-\mathrm{Bipy}-8 \mathrm{w}$ spectrum. In addition, after 8 washings the spectrum is similar to that observed for anatase synthesized without glutamic acid..$^{25}$ This observation could be attributed to the presence of residual surface adsorbed organic impurities such as glutamic acid which are progressively released from surface with washings.

Moreover, the position and the FWHM of optical bands depend on the size of the crystallites. ${ }^{25}$ The shift of the $\mathrm{E}_{\mathrm{g}}(1)$ band towards lower frequencies and its extension for $\mathrm{TiO}_{2}$ A-Bipy-3w spectrum $\left(\approx 165 \mathrm{~cm}^{-1}\right.$ for $\mathrm{TiO}_{2}$-A-Bipy-3w and $\approx 150 \mathrm{~cm}^{-1}$ for $\mathrm{TiO}_{2}$-A-Bipy- $\left.8 \mathrm{w}\right)$ suggested that the crystallites are smaller than for $\mathrm{TiO}_{2}-\mathrm{A}-\mathrm{Bipy}-8 \mathrm{w}$, thus confirming the samples size calculated from the XRD diffractograms.

The morphology of the $\mathrm{TiO}_{2}$ samples was analyzed by TEM and HR-TEM. Pictures of Figure 3 show non truncated bipyramids. In addition, the nanoparticles are homogeneous in size and morphology and no amorphous compound is present (figure 3 and figure S1 in SI). All the observed lattices on $\mathrm{TiO}_{2}$-A-Bipy-8w particles confirm that the lateral sides of the bipyramids correspond to $\{101\}$ faces. Similar observations were made for AGu- $3 w$ as previously observed. ${ }^{20}$

These samples exhibit morphology close to the macro sized crystals morphology found in mineralogy as truncated square bipyramids exposing mainly the $\{101\}$ faces and lower amounts of $\{001\}$ faces on the tops. This morphology corresponds to that obtained by GibbsWulf construction which shows that the $\{101\}$ faces are the most stable. In the case of a nontruncated bipyramid anatase, the ratio between the height and the side of its base is 2.51 (since the angle between the $\{101\}$ and $\{001\}$ faces is $68.3^{\circ}$ ). Here the anisotropy ratio is 2.4 , leading us to conclude that there is few $\{001\}$ faces and the bipyramids are close to nontruncated bipyramids. As observed on fig 3 besides non truncated bipyramids exposing exclusively $\{101\}$ faces, we can also observe irregular nanoparticles exhibiting one pointed apex and one truncated apex. The angle underlying in blue is $111^{\circ}$ whereas the theoretical angle between $\{101\}$ and $\{00-1\}$ faces is 111.7 . This confirms the attribution of $\{001\}$ faces on the apex. Furthermore, some particles exhibit steps as defects which correspond to $\{101\}$ steps. These irregular nanoparticles come from oriented attachment of two (or more) 
bipyramids. $^{31}$

The average sizes of the particles correspond to the size of the crystallites measured by XRD for $\mathrm{TiO}_{2}-\mathrm{A}-\mathrm{Bipy}-3 \mathrm{w}$ and $\mathrm{TiO}_{2}-\mathrm{A}-\mathrm{Bipy}-8 \mathrm{w}$, showing that the particles are monocrystalline. The as-synthesized $\mathrm{TiO}_{2}-\mathrm{A}-\mathrm{Bipy}-8 \mathrm{w}$ nanoparticles displayed a relative high specific surface area of $190 \mathrm{~m}^{2} \mathrm{~g}^{-1}$ but the highest one was $215 \mathrm{~m}^{2} \mathrm{~g}^{-1}$ for $\mathrm{TiO}_{2}$-A-Bipy-3w, in agreement with smaller particles size. The main characterization details are summarized in Table 1 and characteristics of $\mathrm{TiO}_{2}-\mathrm{P} 25$ nanoparticles used are also reported. In literature, this morphology is commonly reported, even if the aspect ratio varies, since the natural growth leads to perfect or truncated bipyramids formation. ${ }^{32}$

From the results of these different characterization techniques, the extended washings were found to apparently impact only slightly on the characteristics of the $\mathrm{TiO}_{2}$-A-Bipy samples . The only difference lies in the residual amount of glutamic acid at the particles surface (by TGA analysis, we measured an organic amount of about $6 \%$ for $\mathrm{TiO}_{2}-\mathrm{A}-\mathrm{Bipy}-3 \mathrm{w}$ and much less for $\mathrm{TiO}_{2}$-A-Bipy-8w).

As already reported in the literature, $\mathrm{TiO}_{2}-\mathrm{P} 25$ is a mixture of anatase or rutile with different ratio according to batch production. ${ }^{16}$ The $\mathrm{TiO}_{2}-\mathrm{P} 25$ anatase nanoparticles seem to expose mainly the $\{101\}$ and $\{001\}$ faces but more reactive faces cannot be excluded due to the large diversity of shapes (bipyramids, platelets and more isotropic particles) ${ }^{33,34}$ In terms of specific surface, the $\mathrm{TiO}_{2}-\mathrm{P} 25$ sample exhibited the lowest specific area with $50 \mathrm{~m}^{2} \mathrm{~g}^{-1}$. this value can be explained, firstly, by the fact that the particles are larger than in $\mathrm{TiO}_{2}-\mathrm{A}-\mathrm{Bipy}$ and there are also rutile particles with larger sizes. Secondly the particles are highly aggregated, leading to an much smaller accessible area.

\subsection{Evaluation of photocatalytic activities of the $\mathrm{TiO}_{2}$ samples}

Reference experiments were first done to ensure that no detectable degradation occurred without titania powders nor UV radiation exposure. The photocatalytic degradation of the three organic pollutants, $\mathrm{RhB}$, phenol and formic acid was then performed according to the procedure described above.

\subsubsection{Rhodamine B degradation}


$\mathrm{RhB}$ was first used as a representative dye molecule to evaluate the photocatalytic activity of the synthesized $\mathrm{TiO}_{2}$ samples under UV-A radiation exposure. The serious environmental problems associated with the industrial use of toxic organic compounds as textile dyes, bleaching agent paper, and in leather industries still causes environmental pollution. ${ }^{35}$ Moreover, the use of $\mathrm{RhB}$ to evaluate photocatalytic activity of $\mathrm{TiO}_{2}$ samples presents two main benefits (i) a fast kinetic degradation and (ii) an easy way to monitor the $\mathrm{RhB}$ concentration through visible spectroscopic method. That is clearly what has been used in a significant part of the published articles on photocatalysis.

The disappearance kinetics of $\mathrm{RhB}$ in presence of $\mathrm{TiO}_{2}-\mathrm{A}-\mathrm{Bipy}-3 \mathrm{w}, \mathrm{TiO}_{2}-\mathrm{A}-\mathrm{Bipy}-8 \mathrm{w}$ and $\mathrm{TiO}_{2}-\mathrm{P} 25$ under UV-A radiation exposure with a 30-minutes dark adsorption period is shown on Figure 4.

After the 30-minutes dark adsorption period, the concentration of $\mathrm{RhB}$ in the aqueous suspension slightly decreased in presence of both $\mathrm{TiO}_{2}$-A-Bipy samples due to the adsorption of the dye molecule on their surfaces (about 7\% and $9 \%$ of initial $\mathrm{RhB}$ concentration for $\mathrm{TiO}_{2}$-A-Bipy-8w and $\mathrm{TiO}_{2}$-A-Bipy-3w respectively). In contrast, the amount of adsorbed $\mathrm{RhB}$ on $\mathrm{TiO}_{2}-\mathrm{P} 25$ was negligible. The higher adsorption of $\mathrm{RhB}$ on $\mathrm{TiO}_{2}$-A-Bipy could result from their higher specific surface, since the surface for $\mathrm{TiO}_{2}$-A-Bipy samples is almost four times higher than for $\mathrm{TiO}_{2}-\mathrm{P} 25$. It may be also due to the difference of the surface acidity (see later in this discussion). Since $\mathrm{TiO}_{2}$-A-Bipy exhibits stronger acid sites than $\mathrm{TiO}_{2}-\mathrm{P} 25$, the adsorption of $\mathrm{RhB}$ is favoured on the former, as the $\mathrm{RhB}$ is a basic dye. Under UV-A radiation, all photocatalytic degradation followed an apparent first-order kinetic model confirmed by the linear transforms $\ln \left(\mathrm{C}_{0} / \mathrm{C}\right)=\mathrm{kt}$ where $\mathrm{k}$ is the apparent reaction rate constant, $\mathrm{C}_{0}$ and $\mathrm{C}$ are the concentration of $\mathrm{RhB}$ after adsorption and the concentration of $\mathrm{RhB}$ at time $\mathrm{t}$ (insert Figure 4). No hypsochromic shift of absorption bands was observed for all experiments, thus suggesting that adsorption of $\mathrm{RhB}$ through its positively charged diethylamino group was a minority phenomenon. ${ }^{36,37}$ The disappearance of $\mathrm{RhB}$ was significantly faster in the presence of the synthesized $\mathrm{TiO}_{2}-\mathrm{A}-\mathrm{Bipy}-8 \mathrm{w}$ and $-3 \mathrm{w} \mathrm{TiO}_{2}$ samples (98\% for the 60-minutes time) compared to the commercial - $\mathrm{TiO}_{2}-\mathrm{P} 25(70 \%)$. The apparent rate constants (initial disappearance rates) were $6.73 \mathrm{~min}^{-1}\left(1.25 \mathrm{ppm} \min ^{-1}\right), 4.63 \min ^{-1}(0.98$ ppm $\left.\min ^{-1}\right)$ and $1.37 \mathrm{~min}^{-1}\left(0.54 \mathrm{ppm} \mathrm{min}^{-1}\right)$ for $\mathrm{TiO}_{2}-\mathrm{A}-\mathrm{Bipy}-8 \mathrm{w}, \mathrm{TiO}_{2}-\mathrm{A}-\mathrm{Bipy}-3 \mathrm{w}$ and $\mathrm{TiO}_{2}-$ $\mathrm{P} 25$ respectively. Normalizing the rate with respect to the surface area does not change this 
order $\left(6.610^{-3}, 4.610^{-3}\right.$ and $2,710^{-3} \mathrm{ppm}^{-1} \mathrm{~min}^{-2} \mathrm{~g}$ respectively). Additional washings of $\mathrm{TiO}_{2}$-A-Bipy-8w enhanced the photocatalytic efficiency. From that first test we may claim that the bipyramids are better photocatalytic materials than the reference system $\mathrm{TiO}_{2}-\mathrm{P} 25$. The test was indeed performed in experimental conditions where $\mathrm{TiO}_{2}-\mathrm{P} 25$ should present the best efficiency (1g.L $\mathrm{L}^{-1}$ of photocatalyst and a strong contribution of UV light in the used lamp). However, the choice itself of the pollutant may induce a bias in the test; the dye probe is able to act as an electron donor injecting electrons from its excited state to the conduction band of the semiconductor, as RhB adsorbs in visible and UV-A radiation ranges both emitted by the HPK 125 light source. Photobleaching of the dye can thus partially contribute to its oxidation and lead to a decrease of its concentration as the same time as the illuminated $\mathrm{TiO}_{2}$ powder. Moreover, the RhB photocatalytic degradation mainly occurs via direct oxidation on $\mathrm{TiO}_{2}$ surface which is not the case with other model molecule that less strongly adsorb on the photocatalyst.

\subsubsection{Phenol degradation}

In view of the dye sensitization mechanism, the photocatalytic degradation of phenol was then studied. Phenol was chosen as a model pollutant because of (i) it is largely used in plastic and pharmacy industries, (ii) its low adsorption ability on $\mathrm{TiO}_{2}$ surface and (iii) the possibility it offers to monitor the formation of by-products generated during its degradation by photocatalysis. Moreover, in addition to $\mathrm{RhB}$, the use of phenol to assess the photocatalytic activity of $\mathrm{TiO}_{2}$ samples is of particular interest as its degradation mainly involves oxidation through a hydroxyl radical-mediated pathway at low concentrations.$^{29,38-40}$ Figure 5 displays the disappearance of phenol concentration as a function of UV-A radiation exposure time in presence of $\mathrm{TiO}_{2}$-A-Bipy and $\mathrm{TiO}_{2}-\mathrm{P} 25$ photocatalysts.

After the 30-minutes dark period, we observed a slight adsorption of phenol on each $\mathrm{TiO}_{2}$ samples (9\% for $\mathrm{TiO}_{2}-\mathrm{A}-\mathrm{Bipy}-3 \mathrm{w}, 1 \%$ for $\mathrm{TiO}_{2}-\mathrm{A}-\mathrm{Bipy}-8 \mathrm{w}$ and $6 \%$ for $\left.\mathrm{TiO}_{2}-\mathrm{P} 25\right)$, despite their different specific surfaces. This could thus correspond to non-specific adsorption due to different surface properties of the three photocatalysts.

Under UV-A radiation exposure, the photocatalytic degradation of phenol is an apparent first- 
order reaction (insert of Figure 5). The order of apparent rate constants (initial disappearance rates resp.) was found to be as followed: $\mathrm{TiO}_{2}-\mathrm{P} 25>\mathrm{TiO}_{2}-\mathrm{A}-\mathrm{Bipy}-8 \mathrm{w}>\mathrm{TiO}_{2}-\mathrm{A}-\mathrm{Bipy}-3 \mathrm{w}$ with values of $2.23 \mathrm{~min}^{-1}(0.26 \mathrm{ppm} \mathrm{min}-1), 1.09 \mathrm{~min}^{-1}\left(0.16 \mathrm{ppm} \mathrm{min}{ }^{-1}\right)$ and $0.65 \min ^{-1}(0.065$ $\mathrm{ppm} \mathrm{min}^{-1}$ ) respectively. Normalizing the rate with respect to the surface area does not change this order. In contrast with the photocatalytic degradation of $\mathrm{RhB}$, commercial $\mathrm{TiO}_{2}$ exhibited the higher phenol degradation.

Previous studies have demonstrated that the benzene ring structure of phenol reacts easily with the $\mathrm{HO} \bullet$ during the photocatalytic process. ${ }^{38,41}$ Among the oxidation intermediates, the formation of hydroquinone, catechol and benzoquinone was monitored during the photocatalytic degradation of phenol (not shown). Although the variations of the three byproducts concentration were slightly different for the two samples, as for $\mathrm{TiO}_{2}-\mathrm{P} 25$, we observed that the phenol was totally degraded and the whole intermediates remained in small amounts throughout the conversion.

\subsubsection{Formic acid}

Since the degradation of the two previous pollutants did not lead to similar results, we have chosen a last model pollutant that may be degraded both by direct hole transfer ans by photogenerated surface radicals. The photocatalytic degradation of formic acid was thus investigated for three main reasons (i) it exhibits simple molecular structure considered as the last molecule formed before conversion into $\mathrm{CO}_{2}$ and $\mathrm{H}_{2} \mathrm{O}$, that makes it a key compound in photocatalytic process (formation of intermediates during its photocatalytic decomposition is very limited).$^{42}$, (ii) it is formed as a classical by-product during the degradation of numerous harmful organic pollutants and (iii) its degradation may proceed through the photo-Kolbe mechanism (equation 1) or via indirect pathways such as $\mathrm{OH}^{\bullet}$ radical attack (equation 2):

$$
\begin{aligned}
& \mathrm{HCCO}_{(\mathrm{aq})}^{-}+\mathrm{h}^{+} \rightarrow \mathrm{CO}_{2(\mathrm{~g})}+\mathrm{H}_{(\mathrm{aq})} \\
& \mathrm{HCCO}_{(\mathrm{aq})}^{-}+\mathrm{HO}^{\bullet} \rightarrow \mathrm{CO}_{2}{ }_{(\mathrm{aq})}^{=}+\mathrm{H}_{2} \mathrm{O}_{(\mathrm{l})}
\end{aligned}
$$

Kinetics of formic acid in presence of $\mathrm{TiO}_{2}-\mathrm{A}-\mathrm{Bipy}-3 \mathrm{w}, \mathrm{TiO}_{2}-\mathrm{A}-\mathrm{Bipy}-8 \mathrm{w}$ and $\mathrm{TiO}_{2}-\mathrm{P} 25$ powders under UV-A radiation exposure is shown on Figure 6. 
After the adsorption dark period, similar amounts of formic acid seemed to be adsorbed on each type of oxides samples: $13 \%$ for $\mathrm{TiO}_{2}-\mathrm{P} 25,10 \%$ for $\mathrm{TiO}_{2}-\mathrm{A}-\mathrm{Bipy}-3 \mathrm{w}$ and $9 \%$ in the case of $\mathrm{TiO}_{2}$-A-Bipy- $8 \mathrm{w}$. A wide range of parameters might influence formic acid adsorption on $\mathrm{TiO}_{2}$ surface such as presence of organic compounds or surface hydration and the adsorption mechanisms are still investigated. ${ }^{43,44}$ Similarly to the other pollutants, degradation reactions under UV-A radiation exposure followed an apparent first-order kinetic model confirmed by the linear transforms $\ln \left(\mathrm{C}_{0} / \mathrm{C}\right)=\mathrm{kt}$ (insert Figure 6). The apparent rate constants (initial disappearance rates resp.) were $6.81 \mathrm{~min}^{-1}\left(1.49 \mathrm{ppm} \mathrm{min}^{-1}\right), 3.63 \mathrm{~min}^{-1}\left(1.06 \mathrm{ppm} \mathrm{min}{ }^{-1}\right)$ and $2.84 \min ^{-1}\left(0.76 \mathrm{ppm} \mathrm{min}^{-1}\right)$ for $\mathrm{TiO}_{2}-\mathrm{P} 25, \mathrm{TiO}_{2}$-A-Bipy-8w and $\mathrm{TiO}_{2}-\mathrm{A}-\mathrm{Bipy}-3 \mathrm{w}$ respectively. Normalizing the rate with respect to the surface area does not change this order. The commercial $\mathrm{TiO}_{2}-\mathrm{P} 25$ displayed a faster photocatalytic degradation rate for formic acid in comparison with both types of $\mathrm{TiO}_{2}$-A-Bipy samples, as observed during the degradation kinetic of phenol considered as a model pollutant.

To summarize the different photocatalytic tests, $\mathrm{TiO}_{2}$-A-Bipy samples and specially the one with enhanced washings exhibited the best photocatalytic efficiency only for RhB degradation. The degradation kinetics of phenol and formic acid were faster with $\mathrm{TiO}_{2}-\mathrm{P} 25$. These results highlighted the fact that the use of single probe molecule is not appropriate to evaluate the efficiency of a photocatalyst, especially owing to photobleaching phenomenon of certain dye molecule used. The changes in the relative efficiency of the studied photocatalysts as function of the molecule used may be correlated to the differences in the involved degradation mechanisms. Indeed, the key parameters for an efficient degradation may differ when the degradation pathway imply a direct charge carrier (generally a hole for an oxidative degradation) transfer on the pollutant at the surface or the mediation of a reactive radical. In both mechanisms, the presence of a higher amount of glutamic acid adsorbed on the surface of $\mathrm{TiO}_{2}$-A-Bipy-3w than on the one of $\mathrm{TiO}_{2}$-A-Bipy- $8 \mathrm{w}$ may partially block the access of the surface to the pollutant or to the reactive radicals' precursors. This could then explain the systematic lower degradation activity of $\mathrm{TiO}_{2}-\mathrm{A}-\mathrm{Bipy}-3 \mathrm{w}$. However, the presence of organic residuals may not explain all the photocatalytic results and additional characterizations more specific to surface properties, charge-carrier dynamics and reactivity were performed. First, FT-IR measurements were carried out to determine the surface reactivity and more specifically the surface acidity that may directly influence the adsorption properties. 


\subsection{Physisorption and $\mathrm{TiO}_{2}$ surface acidity analysis}

FT-IR spectroscopy is an analytical technique that provides accurate information about the chemical structure and the surface activity of $\mathrm{TiO}_{2}{ }^{45-47}$ In the present study, it was used to describe the acid sites of $\mathrm{TiO}_{2}$-A-Bipy samples following adsorption and desorption of pyridine in order to compare their surface reactivity to the one of $\mathrm{TIO}_{2}-\mathrm{P} 25$ reference.

First, the hydroxyls area around $3500-3800 \mathrm{~cm}^{-1}$ can be used to correlate the vibration strength of the $\mathrm{OH}$ surface group to the nature of the exposed surfaces (Figure 7). Indeed, even if this vibration can be due to physisorbed water, Dzwigaj et al. previously reported from both experimental and theoretical studies that the expected wavenumbers for hydroxyls on anatase surfaces depend on the exhibited crystallographic face. ${ }^{48}$ The main peaks for $\mathrm{TiO}_{2}{ }^{-}$ A-Bipy samples around $3640 \mathrm{~cm}^{-1}$ corresponded to $\{101\}$ faces as expected from the TEM study for non-truncated bipyramids morphology. However, $\mathrm{TiO}_{2}$-A-Bipy-3w exhibited several smaller bands at higher wavenumbers that could correspond to $\{100\}$ or $\{001\}$ faces. This could be explained by two potential effects of the supplementary washings: the reconstructions of the highest $\Delta \mathrm{G}$ surfaces on the more stable $\{101\}$ surfaces and the removing of the smallest particles, through additional centrifugation steps, that could exhibit more defects and higher energy surfaces.

The adsorption and thermo-desorption of the pyridine molecule were then studied. Pyridine was used as a basic probe for the qualitative and quantitative analysis of $\mathrm{TiO}_{2}$ surface acid sites, through its temperature $\left(20-200{ }^{\circ} \mathrm{C}\right)$ controlled desorption as its different vibration modes depend on the nature of its surface adsorption site..$^{28,46,47,49}$ The most studied band in the literature for Lewis site is the $v_{8 \mathrm{a}}$ band located around $1585-1615 \mathrm{~cm}^{-1}$, known to be very sensitive to changes in acidity strength.$^{50}$ Indeed, it shifts towards higher wavenumbers when pyridine is bounded to more acidic sites. However, in the case of this study, the remaining of organic additives in $\mathrm{TiO}_{2}$-A-Bipy samples, which did not desorb with the activation, rendered the interpretation in this spectral range difficult. We chose the $v_{12}$ vibration mode of the Lewis acidic sites around $1040 \mathrm{~cm}^{-1}$ (clear of organic residuals signature) that can be correlated to the $v_{8 \mathrm{a}}$ band (Figure 8). ${ }^{51}$ Both the position of the $v_{12}$ vibration mode and its relative area during the desorption can be associated to the strength of the Lewis site. 
The initial quantity of pyridine adsorbed was first assessed $\left(20^{\circ} \mathrm{C}, 133 \mathrm{~Pa}, \mathrm{~d}_{1}\right)$. Considering the same surface for all samples, $\mathrm{TiO}_{2}-\mathrm{A}-\mathrm{Bipy}-3 \mathrm{w}$ displayed the highest pyridine adsorption since $\mathrm{TiO}_{2}$-A-Bipy- $8 \mathrm{w}$ adsorbed about $90 \%$ of this amount (the same trend was observed with the $\mathrm{RhB}$ pollutant during the photocatalytic experiment) and $\mathrm{TiO}_{2}-\mathrm{P} 25$ only $35 \%$. This result indicated that $\mathrm{TiO}_{2}$-A-Bipy samples were more acidic than $\mathrm{TiO}_{2}-\mathrm{P} 25$ towards the pyridine. Moreover, by looking at the peak wavenumbers, we observed for all samples a shift towards higher values with increased temperature, which corresponded to a more acidic behavior of the Lewis sites. For $\mathrm{TiO}_{2}$-A-Bipy-3w, the peak was found at 1042.2 at room temperature $\left(\mathrm{d}_{3}\right)$ and $1044.3 \mathrm{~cm}^{-1}$ for $200{ }^{\circ} \mathrm{C}\left(\mathrm{d}_{7}\right)$. Compared to $\mathrm{TiO}_{2}-\mathrm{A}-\mathrm{Bipy}-8 \mathrm{w}\left(1044.0\right.$ to $\left.1045.2 \mathrm{~cm}^{-1}\right), \mathrm{TiO}_{2^{-}}$ A-Bipy-3w exhibited less acidic sites. The additional washings did not change the number of adsorption site of the pyridine but induced more acid sites on $\mathrm{TiO}_{2}$-A-Bipy- $8 \mathrm{w}$ surface.

For the $\mathrm{TiO}_{2}-\mathrm{P} 25$ sample, the peak shift from $1042.1\left(\mathrm{~d}_{3}\right)$ to $1044.6 \mathrm{~cm}^{-1}\left(\mathrm{~d}_{7}\right)$ with the temperature confirmed quantitatively and qualitatively less acidic sites than $\mathrm{TiO}_{2}-\mathrm{A}-\mathrm{Bipy}-8 \mathrm{w}$.

In addition to the Lewis sites, other adsorption sites were studied in gas phase since they might be of particular importance during the photocatalytic reaction in aqueous solution. An accurate interpretation of this area was difficult because of the smaller dependence of the peaks towards the acidity and of the presence of remaining impurities. The first important region corresponds to the $v_{19 \mathrm{~b}}$ vibration mode of physisorbed pyridine around $1438 \mathrm{~cm}^{-1}$ (Figure A-SI). This band is observed as a shoulder of a stronger band corresponding to the same vibration mode but adsorbed on a Lewis site at $1445 \mathrm{~cm}^{-1}$. For both $\mathrm{TiO}_{2}-\mathrm{A}-\mathrm{Bipy}$ samples the physisorption sites were observed before the $100{ }^{\circ} \mathrm{C}$ heating but the peak disappeared as soon as the heating started for the $\mathrm{TIO}_{2}-\mathrm{P} 25$. Concerning the $\mathrm{v}_{8 \mathrm{a}}$ vibration mode of pyridine on Brönsted sites around $1590 \mathrm{~cm}^{-1}$ (not shown), $\mathrm{TiO}_{2}-\mathrm{A}-\mathrm{Bipy}-8 \mathrm{w}$ exhibited more intense peaks than $\mathrm{TiO}_{2}-\mathrm{A}-\mathrm{Bipy}-3 \mathrm{w}$ and the peaks for $\mathrm{TIO}_{2}-\mathrm{P} 25$ sample were not intense enough in this area to conclude. This confirms that the Brönsted sites are less visible and acidic than the Lewis sites, as already observed on anatase surfaces by Busca $e t$ al. ${ }^{46}$

The study of Brönsted and physisorption sites for the Lewis sites showed that the two $\mathrm{TiO}_{2}-\mathrm{A}-$ Bipy samples exhibited the same kind of acidities, without significant difference in the quantity of sites but in the strength of the acidity (they are slightly more acidic ones for $\mathrm{TiO}_{2}$ A-Bipy-8w). $\mathrm{TiO}_{2}-\mathrm{P} 25$ appeared to display the less acidic $\mathrm{TiO}_{2}$ surface sites among the whole 
samples and for all kind of acidity. This results are in agreement with a previous study on acid-base titration of Brönsted acid sites and calculations using MUSIC model. The work shows that the acidity of the $\{101\}$ faces are due to a higher amount of $\mathrm{m} 1) \mathrm{OH}$ compared to $\{001\}^{52}$

As recently reported,$^{53}$ the photodegradation of the $\mathrm{RhB}$ involves a direct transfer of photogenerated charge carriers on the adsorbed molecule. So, the most efficient photocatalyst for rhodamine B degradation was found to be one that presenting the stronger acidic surface sites. According to such mechanistic hypotheses. This relationship is no more valid to explain the good activity of $\mathrm{TiO}_{2}-\mathrm{P} 25$ with the other two pollutants. In the second degradation pathway related to less complexing pollutant, the generation of charge-carriers in the semiconductor and their efficient conversion into active oxygen radical is of paramount importance. For a better insight of the mechanisms leading to the different photoactivities for phenol disappearance, the study of the charge-carriers' dynamic through TRMC and the measurement of radical species by EPR spectroscopy were performed.

\subsection{TRMC data}

Microwave absorption experiments using TRMC was carried out in order to investigate useful information about the lifetime of the charge carriers produced on the surface of oxide materials exposed to UV radiation. This method is based on the measurement of the change of microwave power reflected by a sample exposed to UV laser pulses. The TRMC principle was described in detail in previous studies..$^{27,40}$ For titanium dioxide semiconductors, the TRMC signal is attributed to electrons as they exhibit much higher mobility relative to hole mobility. ${ }^{54}$ The TRMC signal can be characterized by two parameters. The first one is the maximum intensity value $\left(I_{\max }\right)$, which represents the number of the excess charge-carriers created by the pulse. The second parameter is the decay related to the recombination rate or trapping of the charge carriers. Its interpretation depends on various combined process previously described.$^{54}$ For non-adsorbing compounds such as phenol, TRMC signals can be related to the photocatalytic activity of the $\mathrm{TiO}_{2}$ samples. Figure 9 shows TRMC experiments for each $\mathrm{TiO}_{2}$ powders.

The TRMC signals observed for both $\mathrm{TiO}_{2}-\mathrm{A}-\mathrm{Bipy}-8 \mathrm{w}$ and $\mathrm{TiO}_{2}-\mathrm{A}-\mathrm{Bipy}-3 \mathrm{w}$ samples were quite similar. Additional washings induced a slight decrease of $I_{\max }$ value but did not affect the 
time decay of the $\mathrm{TiO}_{2}-\mathrm{A}-\mathrm{Bipy}-8 \mathrm{w}$ signal. The washing procedure probably removed some surface-adsorbed organic residuals which had significant effects on oxidation reactions but did not influence the charge-carrier lifetime. Therefore, the better photocatalytic activity of $\mathrm{TiO}_{2}$-A-Bipy-8w cannot be explained by surface properties influencing the charge-carrier dynamics. For the $\mathrm{TiO}_{2}-\mathrm{P} 25$ and $\mathrm{TiO}_{2}$-A-Bipy samples, the number of charge-carriers created was significantly different. $\mathrm{TiO}_{2}-\mathrm{P} 25$ showed a more intense signal with longer time decay of the created charge-carriers than for the $\mathrm{TiO}_{2}$-A-Bipy samples. That could explain the better degradation of phenol and formic acid.

\subsection{EPR analysis}

The measurement of radical species such as $\mathrm{HO} \bullet$ or $\mathrm{O}_{2}^{-} \bullet$ ( reactive oxygen species, $\mathrm{ROS}$ ) by spin trapping method was particularly appropriate to highlight at molecular level the dynamics of charge separation in solution, and therefore the photocatalytic efficiency. ${ }^{11,53}$ The focus was put here on the hydroxyl radical and EPR spectra of $\cdot$ DMPO-OH adduct for each $\mathrm{TiO}_{2}$ sample after 15 seconds of UV-A radiation were recorded at room temperature (Figure B SI)

For each $\mathrm{TiO}_{2}$ suspension, a characteristic $\cdot \mathrm{DMPO}-\mathrm{OH}$ spin adduct four lines signal corresponding to the formation of the hydroxyl radical at irradiated $\mathrm{TiO}_{2}$ surface was observed. The intensity of the $\mathrm{TiO}_{2}-\mathrm{P} 25$ signal was significantly higher than the intensities of the $\mathrm{TiO}_{2}$-A-Bipy signals. The evolution of $\cdot \mathrm{DMPO}-\mathrm{OH}$ adduct production with short $\mathrm{UV}$ radiation times was also investigated (Figure 10).

For each UV exposure time, the production of hydroxyl radicals was higher for $\mathrm{TiO}_{2}-\mathrm{P} 25$. As expected, the amount of $\cdot \mathrm{DMPO}-\mathrm{OH}$ adduct significantly decreased with UV irradiation duration for $\mathrm{TiO}_{2}-\mathrm{P} 25$ and $\mathrm{TiO}_{2}-\mathrm{A}-\mathrm{Bipy}-8 \mathrm{w}$ and corresponded to its photocatalytic degradation. In the case of $\mathrm{TiO}_{2}-\mathrm{A}-\mathrm{Bipy}-3 \mathrm{w}$, an increase of the production of adduct was noticed between 15 and 30 seconds and then a slight decrease for the 60 -seconds time. This could be explained by the lower photoactivity of this sample, as reported above for the degradation of the pollutants. The whole EPR study clearly corroborated the results obtained for the photocatalytic degradation of phenol and acid formic and explained the better efficiency of $\mathrm{TiO}_{2}-\mathrm{P} 25$ through the production of reactive oxygen species able to react with organic molecules. Moreover, comparison of EPR data and RhB photocatalytic kinetic clearly 
demonstrated that the better activity of $\mathrm{TiO}_{2}$-A-Bipy for the dye degradation could be directly related to oxidation reactions occurring at the photocatalyst surface.

From the combination of the materials characterizations and the three photocatalytic tests, it is now rather obvious that a good photocatalyst must be tailored for a specific photodegradation application. In the case of the RhB dye degradation, the presence of surface acidic sites stressed here indicates that for a pollutant whose degradation involves a surface hole transfer, the good adsorption of the target molecule must be privileged in the choice of the photocatalytic materials. In the case of $\mathrm{RhB}$, surface acidic sites are interesting. The surface selection may then be useful to optimize the adsorption of the targeted pollutant but it may also be useful to increase photoexited electrons and holes separation. Indeed, certain facets are reported to favor the oxidation (holes are preferentially located on these facets) while others, the reduction (with sub-surface trapped electron) ${ }^{54}$ In the case of anatase the studies are still controversial between $\{001\}^{56}$ and $\{101\} .^{57-58}$ The well-known efficiency of the $\mathrm{TiO}_{2^{-}}$ P25 is associated to the fact that this material generates an important amount of ROS that are useful in a wide range of pollutant degradation pathways. Moreover, even if its surface is not 'optimized' for organic molecule adsorption it is clean enough and it exhibits enough acid sites to be still efficient with adsorbed pollutants. The relevance of enhanced washes for $\mathrm{TiO}_{2}-$ A-Bipy is then both attributed to the increase of available adsorption sites and to the increase of the strength of those sites present on better-defined surfaces. The research in accurate surface selection for the preparation of improved photocatalyst is interesting but must be coupled with fine surface and bulk characterization techniques to ensure good charge separation and mobility as well as their efficient use at the surface.

\section{Conclusion}

In conclusion, we have presented in this survey a complete methodology and in-depth characterization of the surface nanocrystalline bipyramidal anatase $\mathrm{TiO}_{2}$ particles to understand the photocatalyst reactivity during the photodegradation of three different organic pollutants. Since A-Glu exhibited stronger acidic sites than $\mathrm{TIO}_{2}-\mathrm{P} 25$, as shown by the FT-IR results, the enhanced activity of $\mathrm{TiO}_{2}$-A-Bipy for the $\mathrm{RhB}$ dye degradation could be related to a direct oxidation mechanism through reactions occurring at the oxide surface. Oppositely, the TRMC and EPR results contributed to explain the lower activity of $\mathrm{TiO}_{2}$-A-Bipycompared to 
$\mathrm{TiO}_{2}-\mathrm{P} 25$ for phenol and acid formic degradation. Indeed, in case of an indirect degradation mechanism, generation and lifetime of charge carriers forming ROS on the particles surface are the critical steps. We have also discussed the influence of the washing on the photocatalytic degradation of pollutants and we noticed that a lower amount of remaining glutamic acid and maybe better-defined surfaces allowed an improved photocatalytic activity. We showed here that the study of the degradation of a dye as a model pollutant is not sufficient to conclude on the properties making an oxide material an efficient photocatalyst. Moreover, the results in aqueous solution may not be directly transferred to the gas phase because additional parameters have to be taken into account. The hole scientific community would then largely benefit from the definition of a standardized and well-tailored photocatalytic test based on a judicious combination pollutant that would provide a faithful gauge of materials photocatalytic efficiency.

\section{Acknowledgements}

The authors thank J.-M. Kraft from Laboratoire de Reactivite de Surface of UPMC for its help concerning Raman spectroscopy, S. Torelli from IRTSV/LCBM of CEA Grenoble for useful discussions about EPR spectroscopy and S. Kathoum for her help during studies of degradation of Rhodamine.

\section{Funding}

The authors gratefully acknowledge the financial support of the Agence Nationale de la Recherche (ANR) through the PhotoNorm and the Mesonnet projects.

\section{References}

1. J. Herrmann, Topics in Catal. 34 (2005), 49-65.

2. F.Han, V. S. R. Kambala, M. Srinivasan, D. Rajarathnam, R. Naidu, Appl. Catal., A 359 (2009), 25-40.

3. M. Nan, B. Jin, C. W. K. Chow, C. Saint, Water Res., 44 (2010), 2997-3027.

4. J. Zhao, X. D. Yang, Build. Environ., 38 (2003), 645-654. 
5. M. Ni, M. K. H. Leung, D. Y. C. Leung, K. Sumathy, Renewa. \& Sust. Energ. Rev., 11 (2007), 401-425.

6. R. Andreozzi, V. Caprio, A. Insola, R. Marotta, Catal. Today, 53 (1999), 51-59.

7. M. A.Henderson, Surface Sci. Rep., 66 (2011), 185-297.

8. M. Pelaez, N. T. Nolan, S. C. Pillai, M. K. Seery, P. Falaras, A. G. Kontos, P. S. M. Dunlop, J. W. J. Hamilton, J. A. Byrne, K. O’Shea, M. H. Entezari, D. D. Dionysiou, Appl. Catal., B, 125 (2012), 331-349.

9. Q.Sun, Y. Xu, J. Phys. Chem., C, 114 (2010), 18911-18918.

10. Z. Zhang, C. Wang, R. Zakaria, J. Y. Ying, J. Phys. Chem. B, 102 (1998), 10871-10878.

11. A. Fujishima, X. Zhang, D. A. Tryk, Surface Sci. Rep., 63 (2008), 515-582.

12. C. Colbeau-Justin, M. Kunst, D. Huguenin, J. Mater. Sci., 11 (2003), 2429-2437.

13. D. Dvoranová, V. Brezová, M. Mazúr, M. A. Malati, Appl. Catal., B, 37 (2002), 91-105.

14. O. O. Prieto-Mahaney, N. Murakami, R. Abe, B. Ohtani, Chem. Lett., 38 (2009), 7-8.

15. D. C. Hurum, A. G. Agrios, K. A. Gray, T. Rajh, M. C. Thurnauer, J. Phys. Chem., B, 107 (2003), 4545-4549.

16. B. Ohtani, D. Li, R. Abe, J. Photochem. Photobiol., A, 216 (2010), 179-182.

17. S. Pigeot-Rémy, F. Simonet, D. Atlan, J. C. Lazzaroni, C. Guillard, Water Res., 46 (2012), 3208-3218.

18. P. K. J. Robertson, J. M. C. Robertson, D. W. Bahnemann, J. Hazard. Mater., 211-212 (2012), 161-171.

19. K. Kanie, T. Sugimoto, Chem. Commun., (2004)1584-5.

20. O. Durupthy, J. Bill, F. Aldinger, Crystal Growth \& Des. 7 (2007), 2696-2704.

21. T. Sugimoto, X. Zhou, J. Colloid Interface Sci., 252 (2002), 347-53.

22. F. Dufour, S. Cassaignon, O. Durupthy, C. Colbeau-Justin, C. Chanéac, Eur. J. Inorg. Chem., 2012 (2012), 2707-2715.

23. X. Chen, S. S. Mao, Chem. Rev., 107 (2007), 2891-2959.

24. J.-P.Jolivet, C. Froidefond, A.Pottier, C. Chanéac, S. Cassaignon, E. Tronc, P. Euzen, J. Mater. Chem., 14 (2004), 3281-3288.

25. A. Pottier, S. Cassaignon, C. Chanéac, F. Villain, E. Tronc, J.-P. Jolivet, J. Mater. Chem., 13 (2003), 877-882.

26. T. Sugimoto, J. Colloid Interface Sci., 259 (2003), 53-61. 
27. S. Boujday, F. Wünsch, P. Portes, J. Bocquet, C. Colbeau-justin, Solar Energ. Mater. Solar Cells, 83 (2004), 421-433.

28. T.Saison, N. Chemin, C. Chan, O. Durupthy, L. Mariey, J. Phys. Chem., C 115, 5657$5666(2011)$.

29. C. Minero, F. Catozzo, E. Pelizzetti, C. Analitica, U. Torino, Langmuir 8 (1992), 481486.

30. T. Ohsaka, F. Izumi, Y. J. Fujiki, J. Raman Spectrosc., 7 (1978), 321-324.

31. R.L. Penn, J.F. Banfield, Geochim. Cosmochim. Acta, 63(10) (1999), 1549-1557

32. Z. Wei, E. Kowalska, J. Verrett, C. Colbeau-Justin, H. Remita and B. Ohtani, Nanoscale, 7 (2015), 12392

33. L. Mino, G. Spoto, S. Bordiga, A. Zecchina, J. Phys. Chem., C 116 (2012), 1700817018.

34. C. Deiana, M. Minella, G. Tabacchi, V. Maurino, E. Fois, G. Martra, Phys. Chem. Chem. Phys. 15 (2013), 307-315.

35. Q. Lu, W. Gao, J. Du, L. Zhou, Y. Lian, J. Agr. Food Chem. 60 (2012), 4773-4778.

36. T. Watanabe, T. Takirawa, K., J. Phys. Chem. 81 (1977), 1845-1851.

37. F.Chen, J. Zhao, H. Hidaka, Int. J. Photoenergy, 5 (2003), 209-217.

38. A. Sobczynski, Ł. Duczmal, W. Zmudzinski, J. Mol. Catal., A, 213 (2004), 225-230.

39. P. Salvador, Appl. Catal., B, 88 (2009), 50-58.

40. C. A. Emilio, M. I. Litter, M. Kunst, M. Bouchard, C. Colbeau-justin, Langmuir, 22 (2006), 3606-3613.

41. J. Arana, M. E. Pulido, V. M. Rodriguez Lopez, A. Pena Alonso, J. M. Dona Rodriguez, D. O. Gonzalez, J. Pena Pérez, J. Hazard. Mater., 146 (2007), 520-528.

42. M. F. J. Dijkstra, H. J. Panneman, J. G. M. Winkelman, J. J. Kelly, A. A. C. M. Beenackers, Chem. Eng. Sci., 57 (2002), 4895-4907.

43. $\quad$ K. L. Miller, J. L. Falconer, J. W. Medlin, J. Catal., 278 (2011), 321-328.

44. M. Xu, H. Noei, M. Buchholz, M. Muhler, C. Wöll, Y. Wang, Catal. Today, 182 (2012), $12-15$.

45. A. Vimont, J. Lavalley, D. Dambournet, M. Nickkho-amiry, J. M. Winfield, Phys. Chem. Chem. Phys., 11 (2009), 1369-1379.

46. G. Busca, Phys. Chem. Chem. Phys. 1 (1999), 723-736. 
47. M. I. Zaki, M. A. Hasan, F. A. Al-sagheer, L. L. Pasupulety, Colloids Surf. A, Colloids Surfaces A 190(3) (2001), 261-274.

48. S. Dzwigaj, C. Arrouvel, M. Breysse, C. Geantet, S. Inoue, H. Toulhoat, P. Raybaud, J. Catal. 236 (2005), 245-250.

49. A. Travert, A. Vimont, A. Sahibed-dine, M. Daturi, J. Lavalley, Appl. Catal. A 307 (2006), 98-107.

50. P. O. Scokart, P. G. Rouxhet, J. Colloid Interface Sci. 86 (1982), 96-104.

51. H. Leclerc, A. Vimont, J.-C. Lavalley, M. Daturi, A. D. Wiersum, P. L. Llwellyn, P. Horcajada, G. Férey, C. Serre, Phys Chem Chem Phys, 13 (2011), 11748-11756.

52. F.Dufour, S.Pigeot-Remy, O. Durupthy, S. Cassaignon, V. Ruaux, S. Torelli, L. Mariey, F Maugé, C.Chanéac, Appl. Catal., B, 174-175 (2015), 350-360.

53. M. Ali Ahmad, B. Prelot, A. Razafitianamaharavo, J. M. Douillard, J. Zajac, F. Dufour, O. Durupthy, C. Chaneac and F. Villieras, J. Phys. Chem. C, 117 (2013), 4459

54. R. Katoh, A. Huijser, K. Hara, T. J Savenije, L. D. A. Siebbeles, J. Phys. Chem., C, 111 (2007), 10741-10746.

55. R. Li, F. Zhang, D. Wang, J. Yang, M. Li, J.Zhu, X. Zhou, H. Han, C. Li, Nat. Commun., 4 (2013), 1432.

56. T. Ohno, K. Sarukawa, M. Matsumura, New J. Chem., 26 (2002), 1167-1170.

57. N. Wu, J. Wang, D. Nyago Tafen, H. Wang, J.-G. Zheng, J. P. Lewis, X. Liu, S. S. Leonard, A. Manivannan, J. Amer. Chem. Soc., 132(19) (2010), 6679-6685.

58. N. Murakami, Y. Kurihara, T. Tsubota, and T. Ohno, J. Phys. Chem. C, 113(8) (2009), 3062-3069. 
Tables caption

Table 1. Main characteristics of $\mathrm{TiO}_{2}-\mathrm{A}-\mathrm{Bipy}-3 \mathrm{w}, \mathrm{TiO}_{2}-\mathrm{A}-\mathrm{Bipy}-8 \mathrm{w}$ and $\mathrm{TIO}_{2}-\mathrm{P} 25$. 


\section{Figures caption}

Fig. 1. Normalized X-ray diffraction pattern of a) $\mathrm{TiO}_{2}-\mathrm{A}-\mathrm{Bipy}-3 \mathrm{w}$ and b) $\mathrm{TiO}_{2}-\mathrm{A}-\mathrm{Bipy}-8 \mathrm{w}$. Diffractograms were indexed according to the 00-21-1272 ICDD file corresponding to anatase structure

Fig. 2. Normalized Raman spectra of a) $\mathrm{TiO}_{2}-\mathrm{A}-\mathrm{Bipy}-3 \mathrm{w}$ sample and b) $\mathrm{TiO}_{2}-\mathrm{A}-\mathrm{Bipy}-8 \mathrm{w}$ sample

Fig. 3. TEM pictures of a) the $\mathrm{TiO}_{2}-\mathrm{A}-\mathrm{Bipy}-3 \mathrm{w}$ and b) $\mathrm{TiO}_{2}-\mathrm{A}-\mathrm{Bipy}-8 \mathrm{w}$ crystallites; c) HRTEM picture of the $\mathrm{TiO}_{2}$-A-Bipy- $8 \mathrm{w}$ crystallites

Fig. 4. Evolution of RhB concentration according to UV-A radiation exposure time $(4.5 \mathrm{~mW}$ $\mathrm{cm}^{-2}$ ) in presence of $\mathrm{TiO}_{2}$-A-Bipy-3w ( $\left.\square\right), \mathrm{TiO}_{2}$-A-Bipy-8w (ם), and $\mathrm{TIO}_{2}-\mathrm{P} 25(\times)$ powders $\left(1 \mathrm{~g} \mathrm{~L}^{-1}\right)$. Insert: first-order linear transforms $\ln \left(\mathrm{C}_{0} / \mathrm{C}\right)=\mathrm{f}(\mathrm{t})$

Fig. 5. Evolution of phenol concentration according to UV-A radiation exposure time (4.5 $\mathrm{mW} \mathrm{cm}{ }^{-2}$ ) in presence of $\mathrm{TiO}_{2}-\mathrm{A}-\mathrm{Bipy}-8 \mathrm{w}(\boldsymbol{\square}), \mathrm{TiO}_{2}-\mathrm{A}-\mathrm{Bipy}-3 \mathrm{w}(\square)$ or $\mathrm{TIO}_{2}-\mathrm{P} 25(\times)$ powders $\left(1 \mathrm{~g} \mathrm{~L}^{-1}\right)$. Insert: first-order linear transforms $\ln \left(\mathrm{C}_{0} / \mathrm{C}\right)=\mathrm{f}(\mathrm{t})$

Fig 6. Evolution of formic acid concentration according to UV-A radiation exposure time (4.5 $\mathrm{mW} \mathrm{cm}{ }^{-2}$ ) in presence of $\mathrm{TiO}_{2}$-A-Bipy-3w $(\square), \mathrm{TiO}_{2}$-A-Bipy-8w ( $)$ or $\mathrm{TIO}_{2}-\mathrm{P} 25(\times)$ powders $\left(1 \mathrm{~g} \mathrm{~L}^{-1}\right)$. Insert: first-order linear transforms $\ln \left(\mathrm{C}_{0} / \mathrm{C}\right)=\mathrm{f}(\mathrm{t})$

Fig. 7. FT-IR spectra of a) $\mathrm{TiO}_{2}-\mathrm{A}-\mathrm{Bipy}-8 \mathrm{w}$ and b) $\mathrm{TiO}_{2}$-A-Bipy-3w in the hydroxyl groups area

Fig. 8. FT-IR spectra corresponding to the $v_{12}$ pyridine vibration mode and its thermodesorption behaviour (from black $\mathrm{d}_{1}$ to light gray $\mathrm{d}_{7}$ ) for the different samples:

a) $\mathrm{TiO}_{2}$-A-Bipy-3w, b) $\mathrm{TiO}_{2}$-A-Bipy-8w, c) $\mathrm{TIO}_{2}-\mathrm{P} 25$. Vertical dotted lines correspond to the positions of the stronger vibration bands just after pyridine adsorption $\left(\mathrm{d}_{0}\right.$ see experimental section)

Fig. 9. TRMC signals of a) $\mathrm{TiO}_{2}-\mathrm{A}-\mathrm{Bipy}-3 \mathrm{w}$, b) $\mathrm{TiO}_{2}-\mathrm{A}-\mathrm{Bipy}-8 \mathrm{w}$, c) $\mathrm{TIO}_{2}-\mathrm{TiO} 2-\mathrm{P} 25$ reference $\mathrm{A}$ ) as measured and $\mathrm{B}$ ) normalized

Fig. 10. Quantitative comparison of the formation of $\cdot \mathrm{DMPO}-\mathrm{OH}$ adduct in $\mathrm{TiO}_{2}$ samples aqueous suspension for 15 (black bar chart), 30 (white bar chart) and 60 seconds (grey bar chart) of UV-A radiation exposure for $\mathrm{TIO}_{2}-\mathrm{P} 25, \mathrm{TiO}_{2}-\mathrm{A}-\mathrm{Bipy}-8 \mathrm{w}$ and $\mathrm{TiO}_{2}-\mathrm{A}$ Bipy-3w 

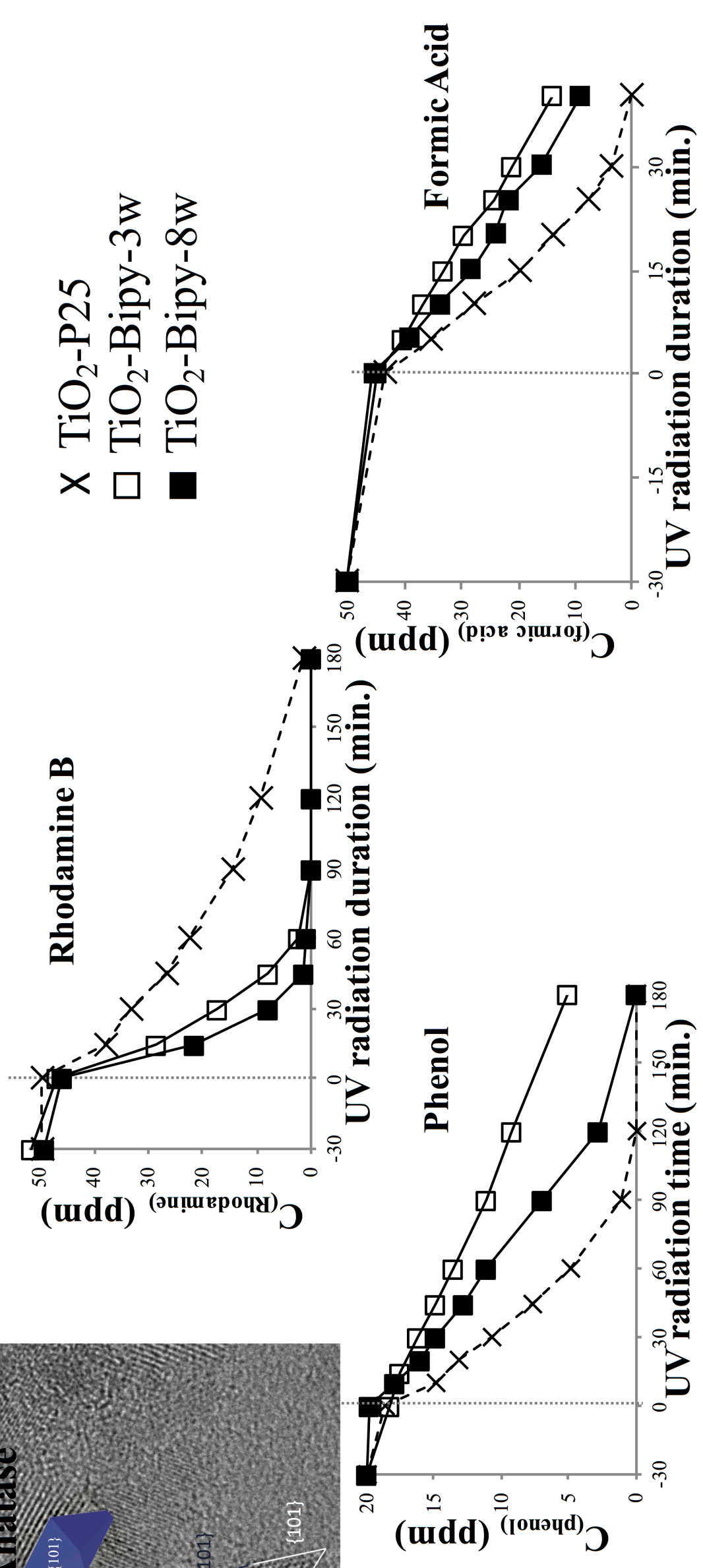
Fig 1

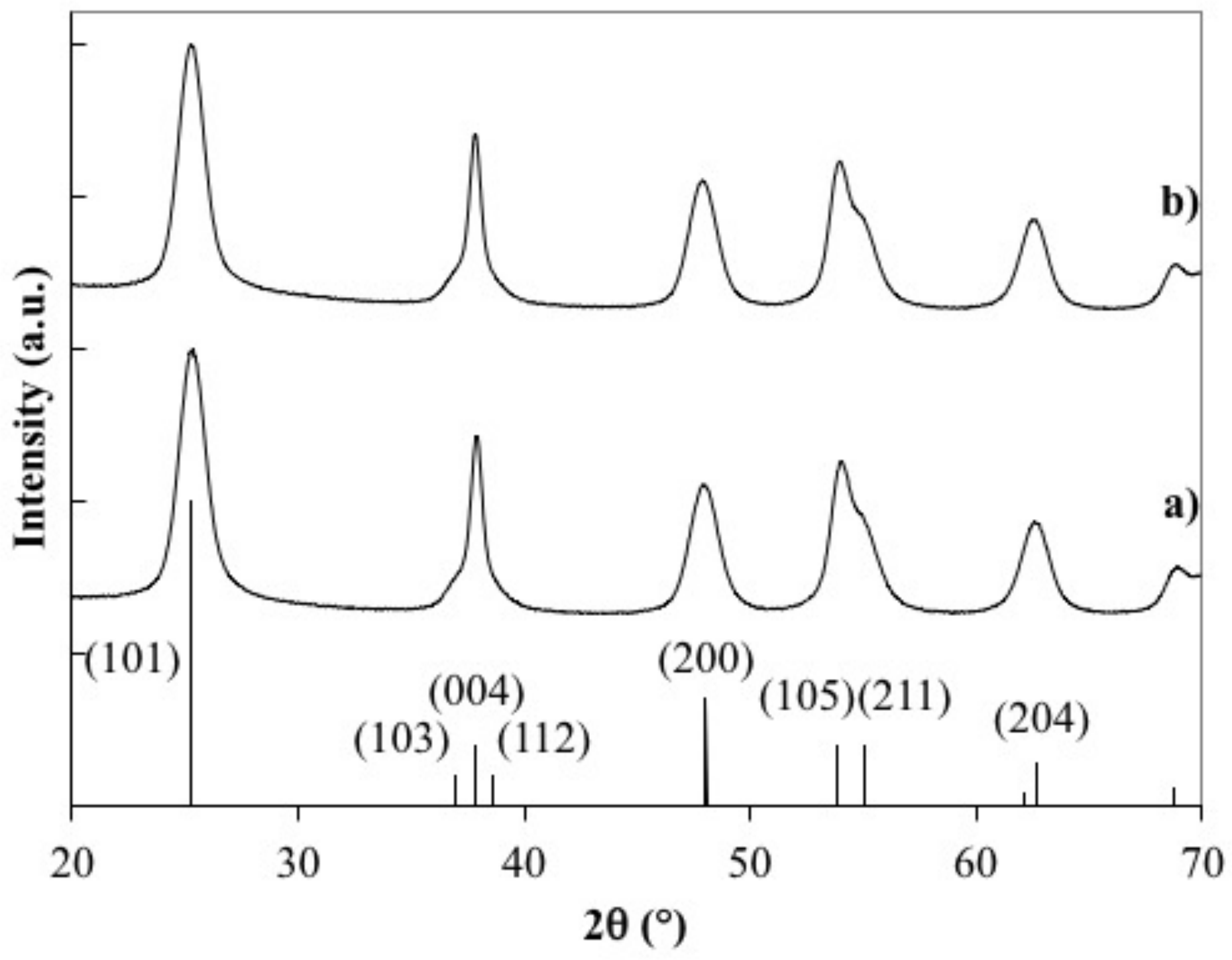


Fig 2

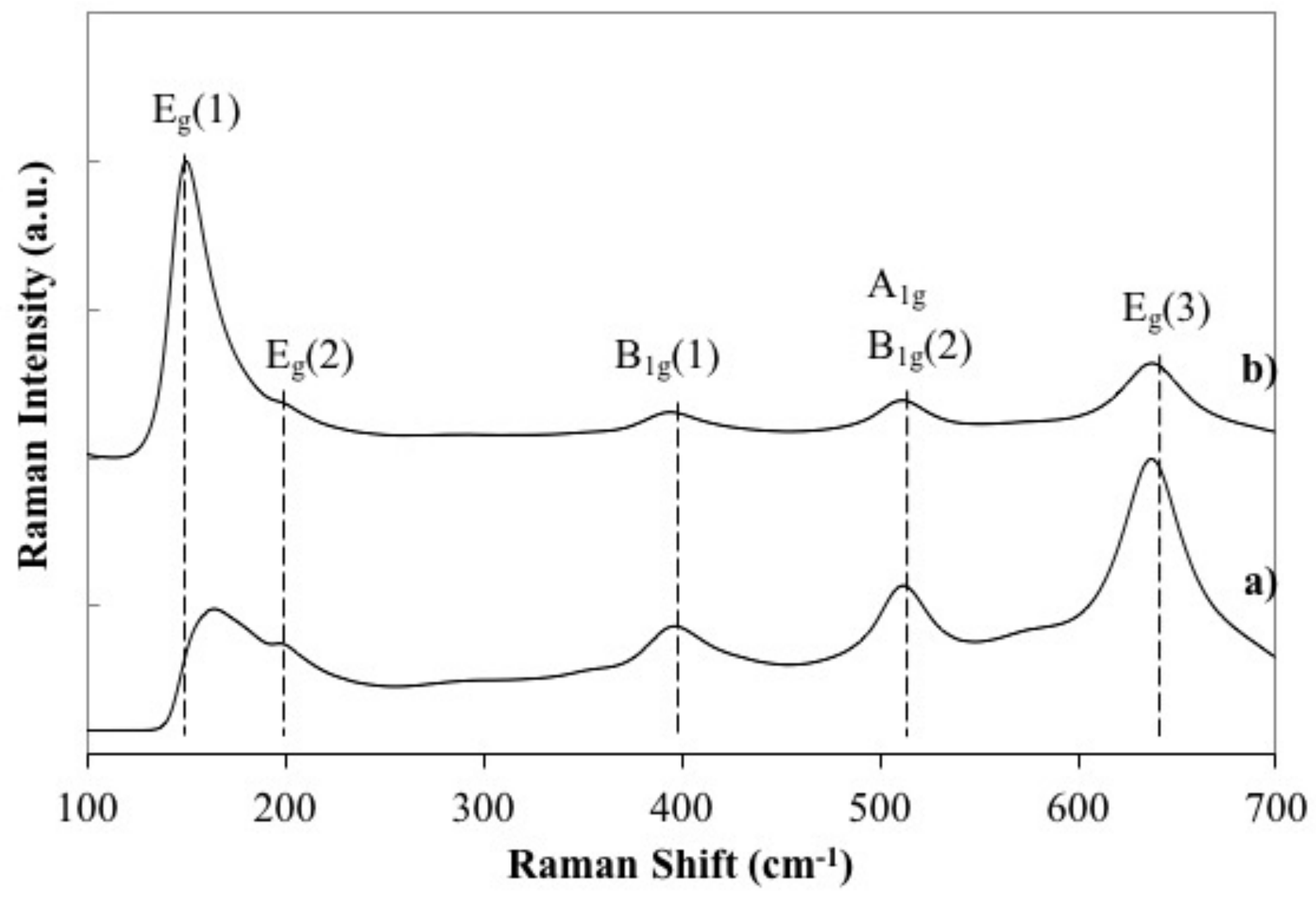




\section{Fig 3}

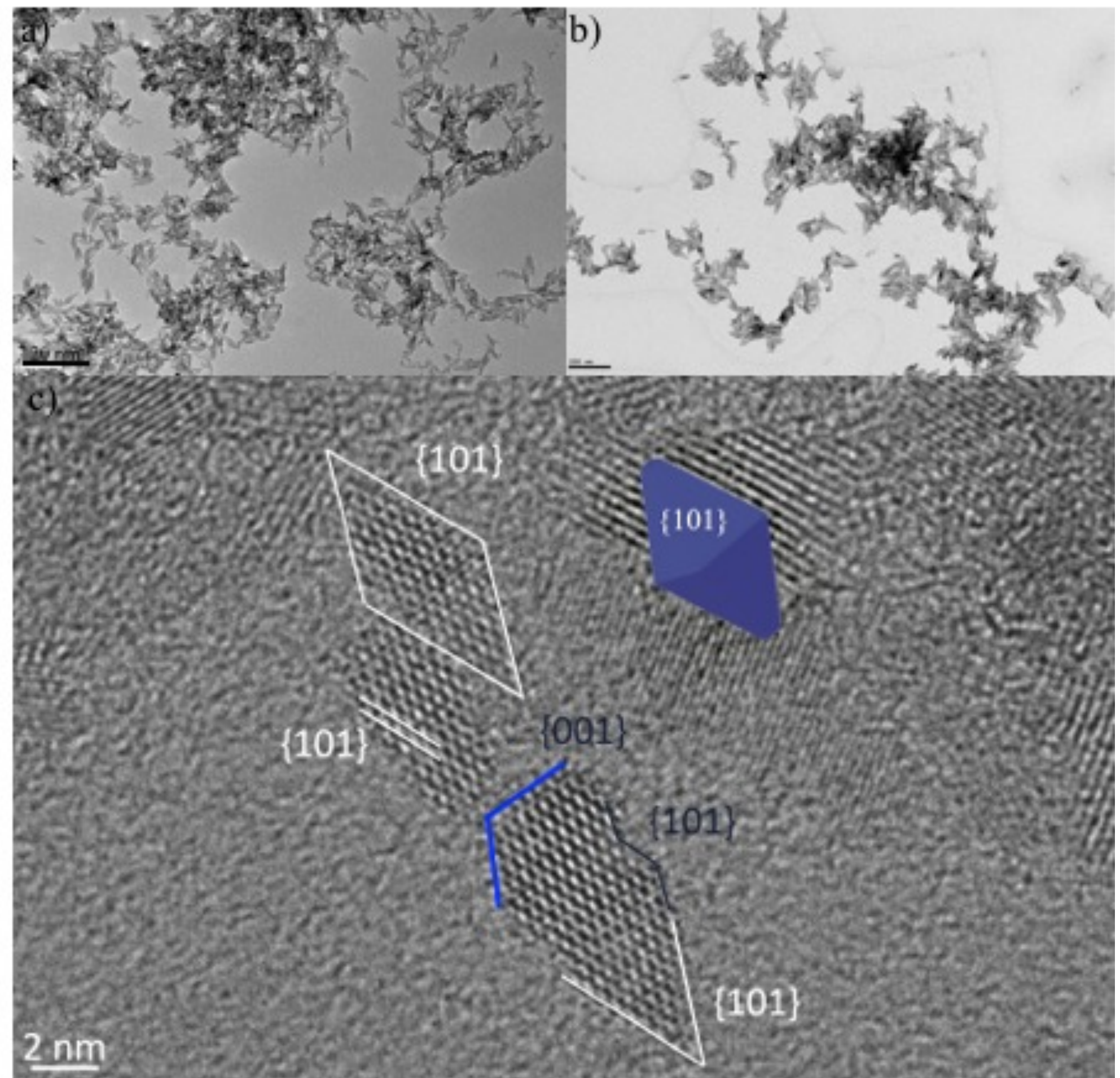


Fig 4

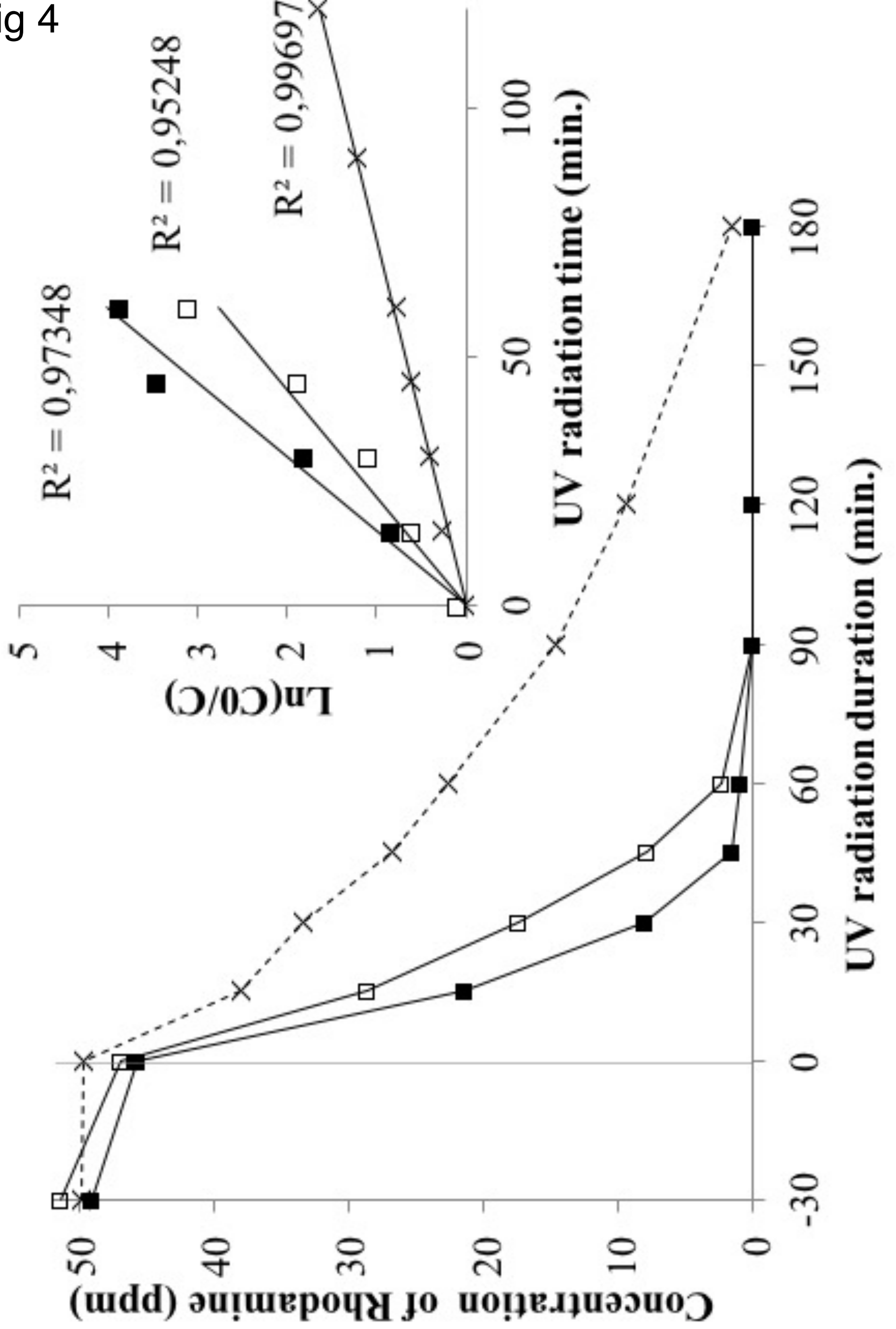


Fig 5

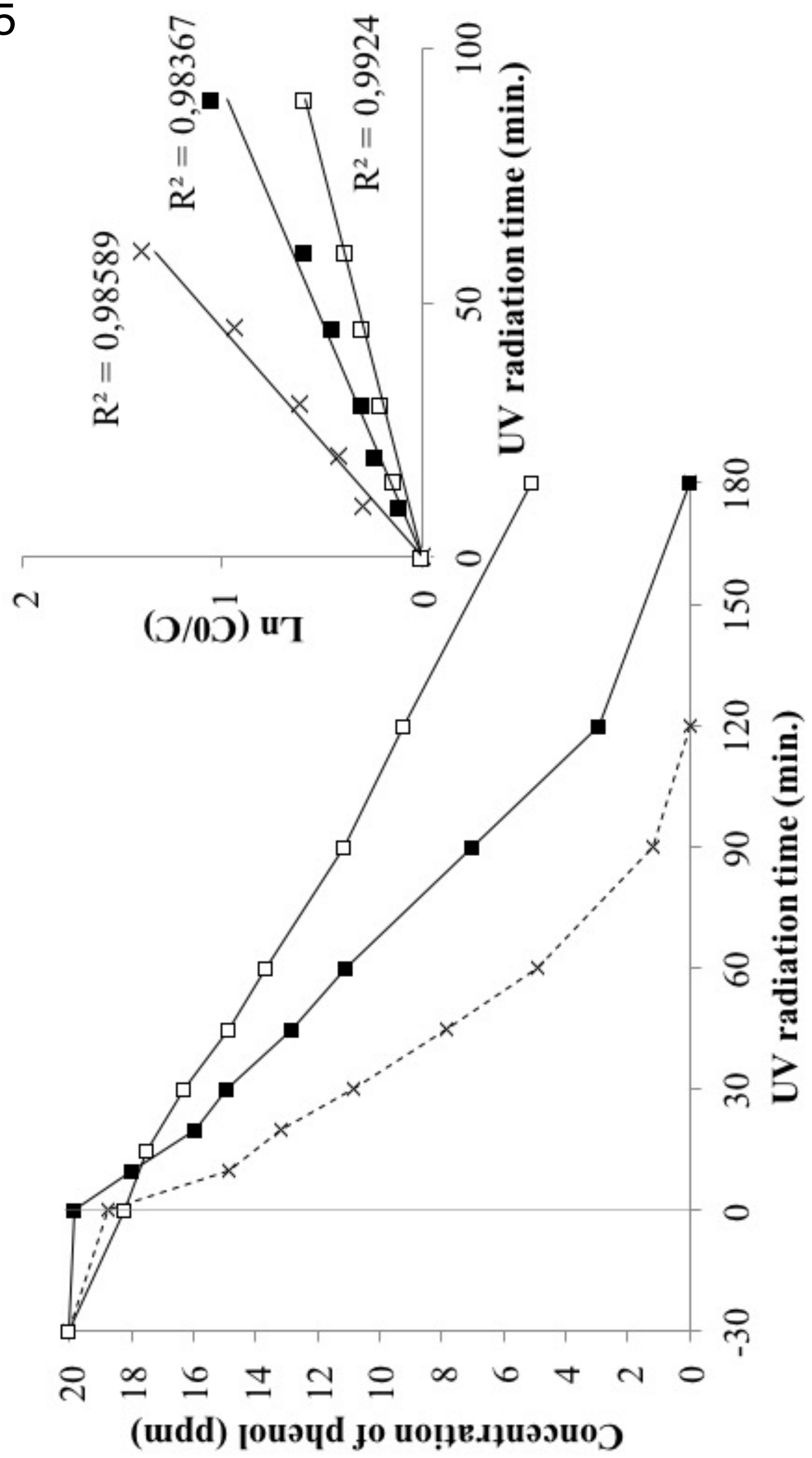


Fig 6

우

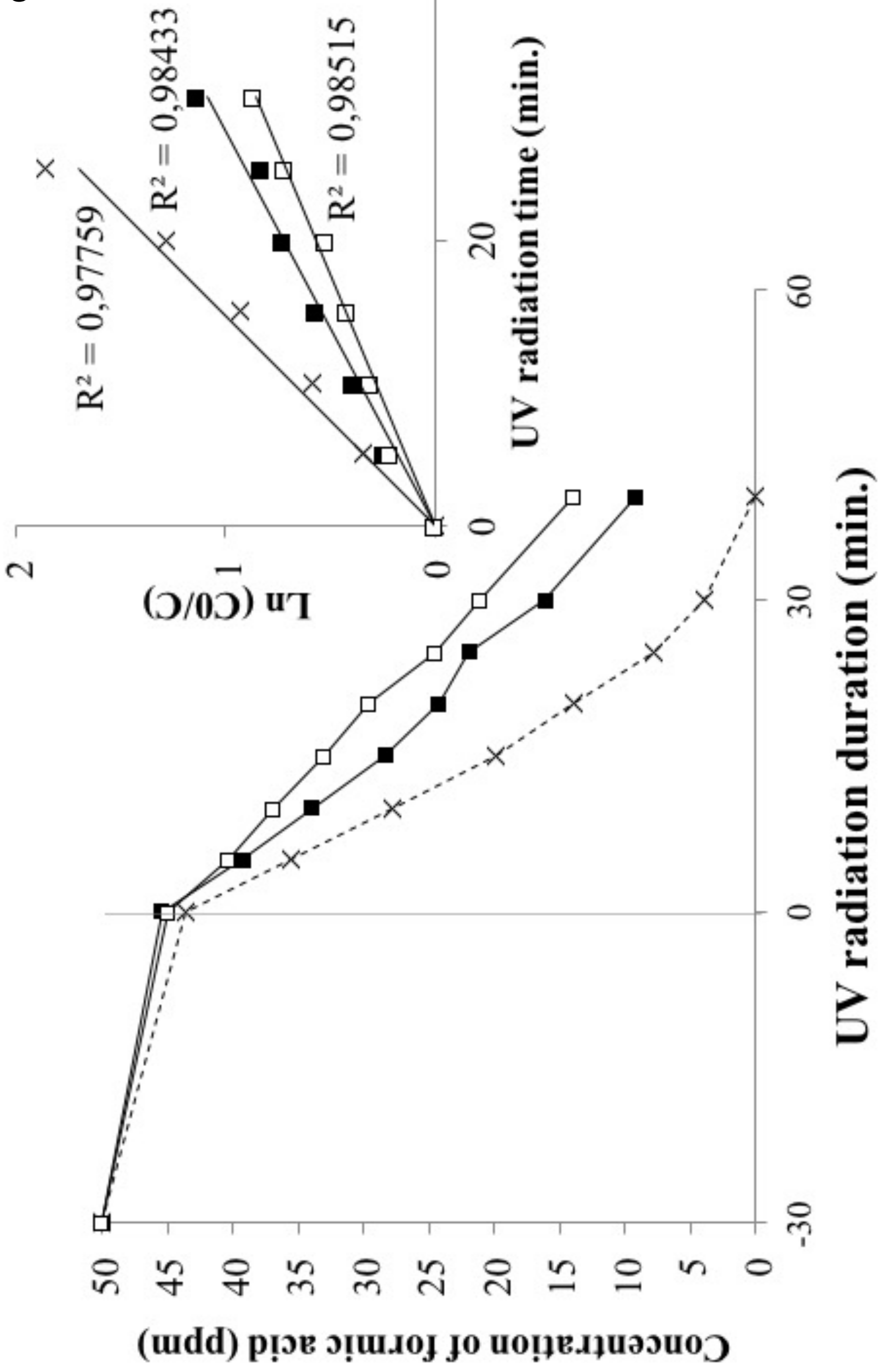


Fig 7

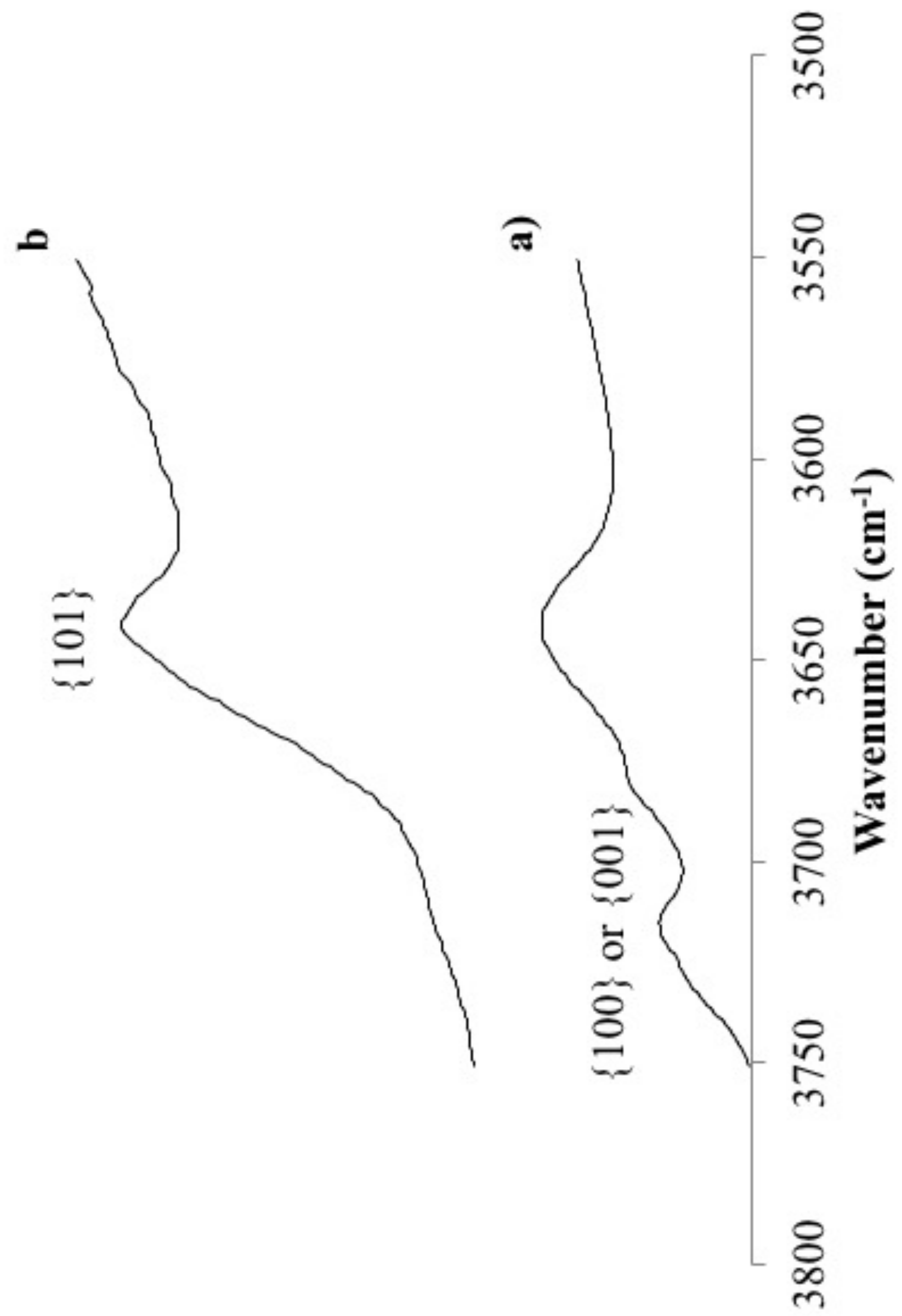


Fig 8
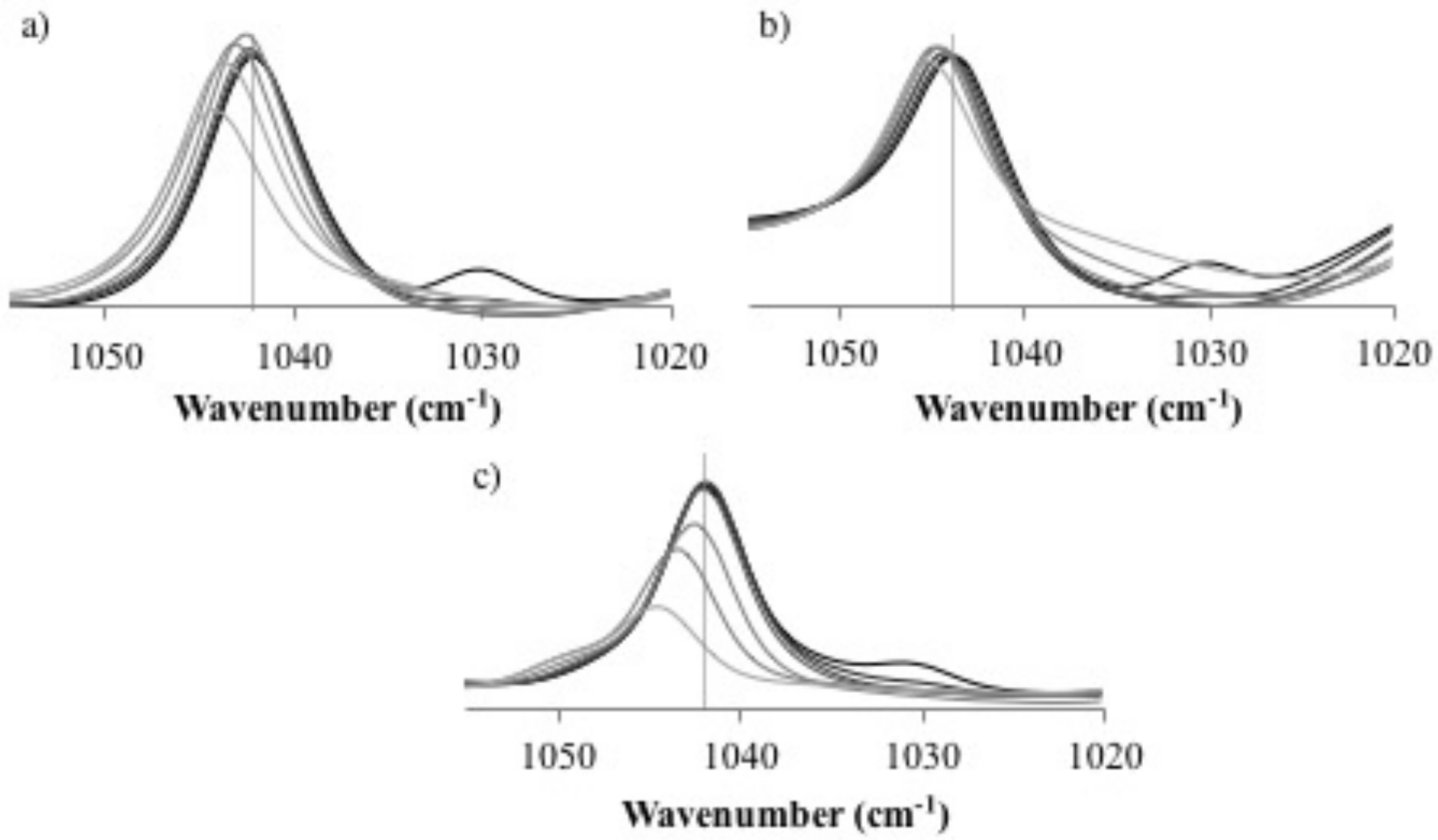
Fig 9
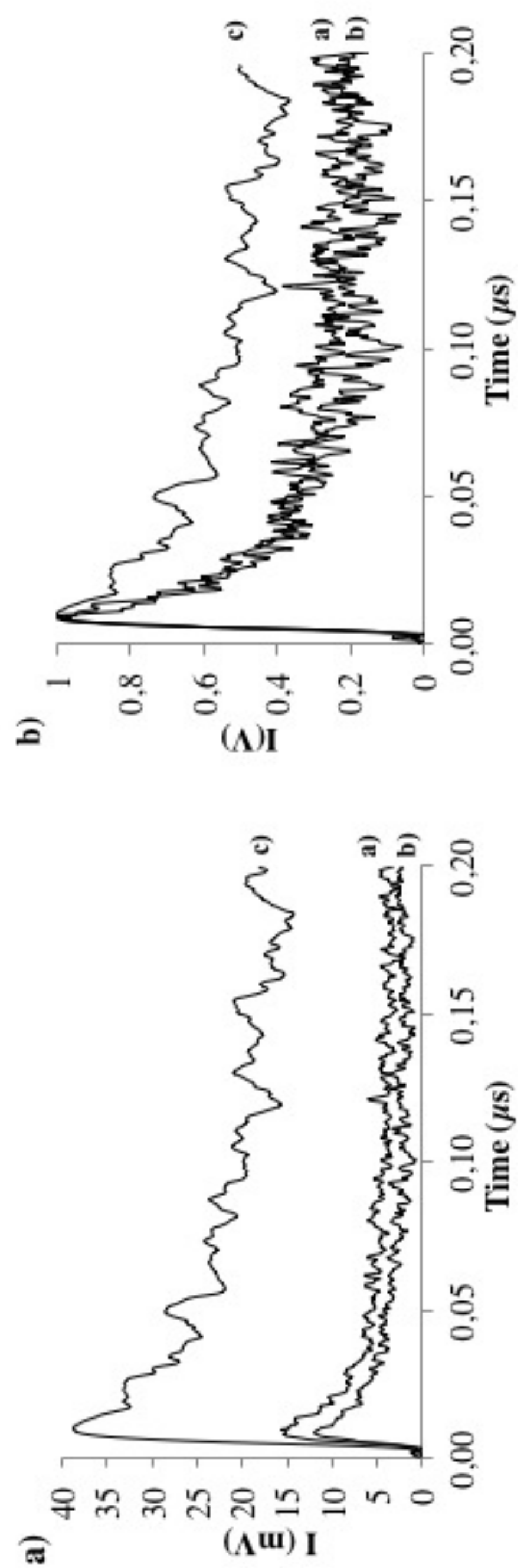
Fig 10

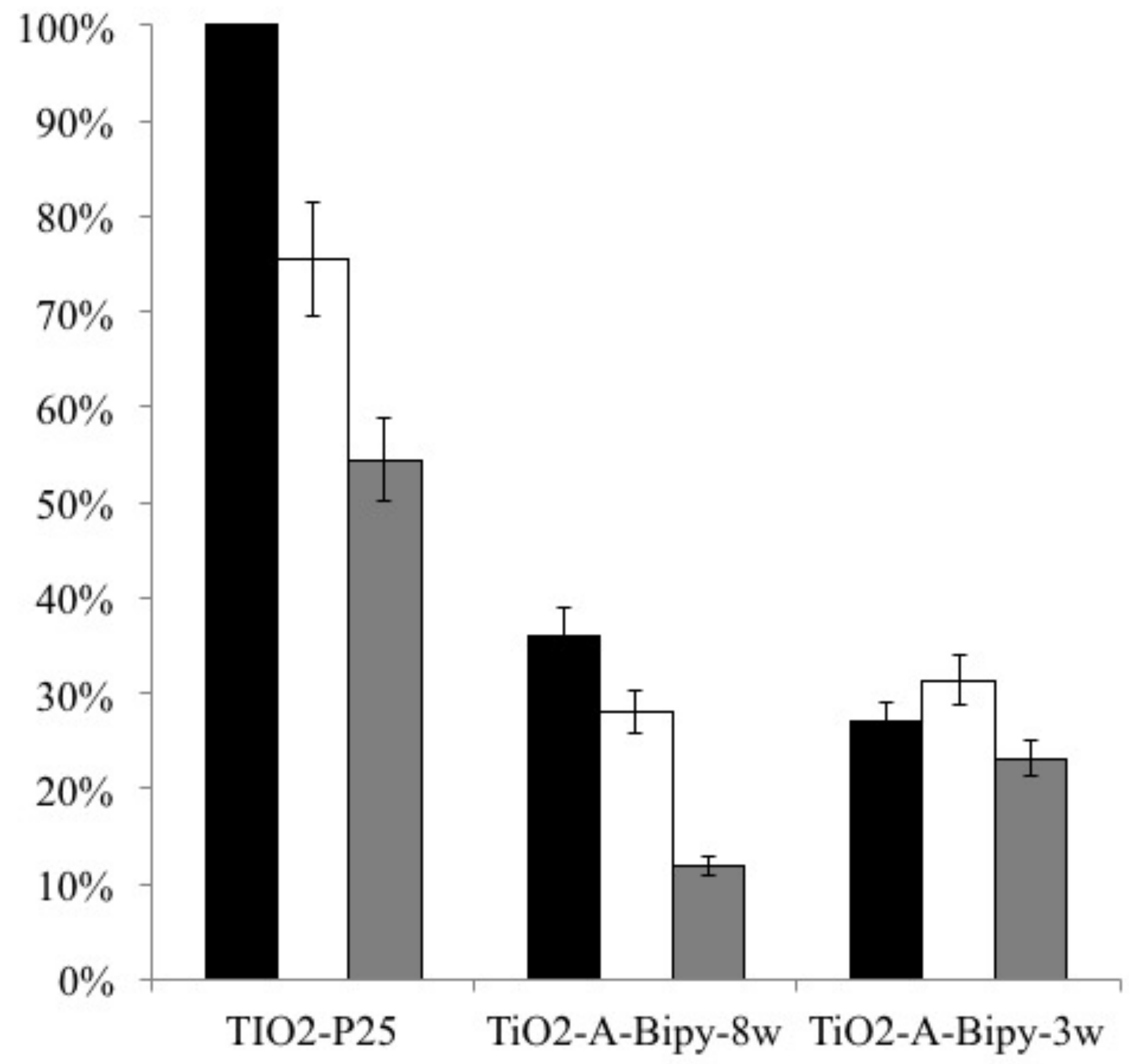

